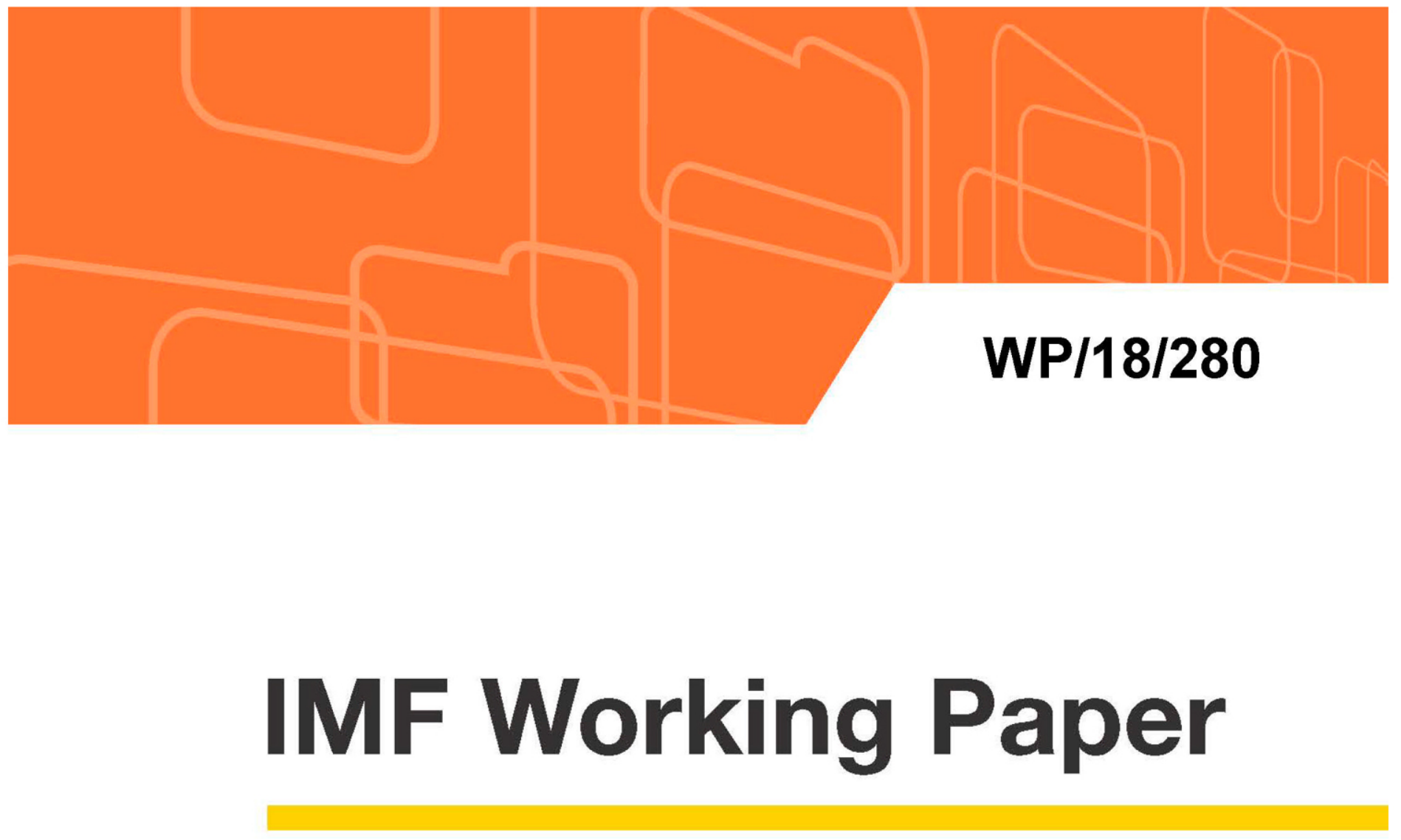

\title{
Expectations' Anchoring and Inflation Persistence
}

\author{
by Rudolfs Bems, Francesca Caselli, Francesco \\ Grigoli, Bertrand Gruss, and Weichen Lian
}

IMF Working Papers describe research in progress by the author(s) and are published to elicit comments and to encourage debate. The views expressed in IMF Working Papers are those of the author(s) and do not necessarily represent the views of the IMF, its Executive Board, or IMF management.
I N
E P
N A T
N A L
M
- N E T A R Y
F U N D 


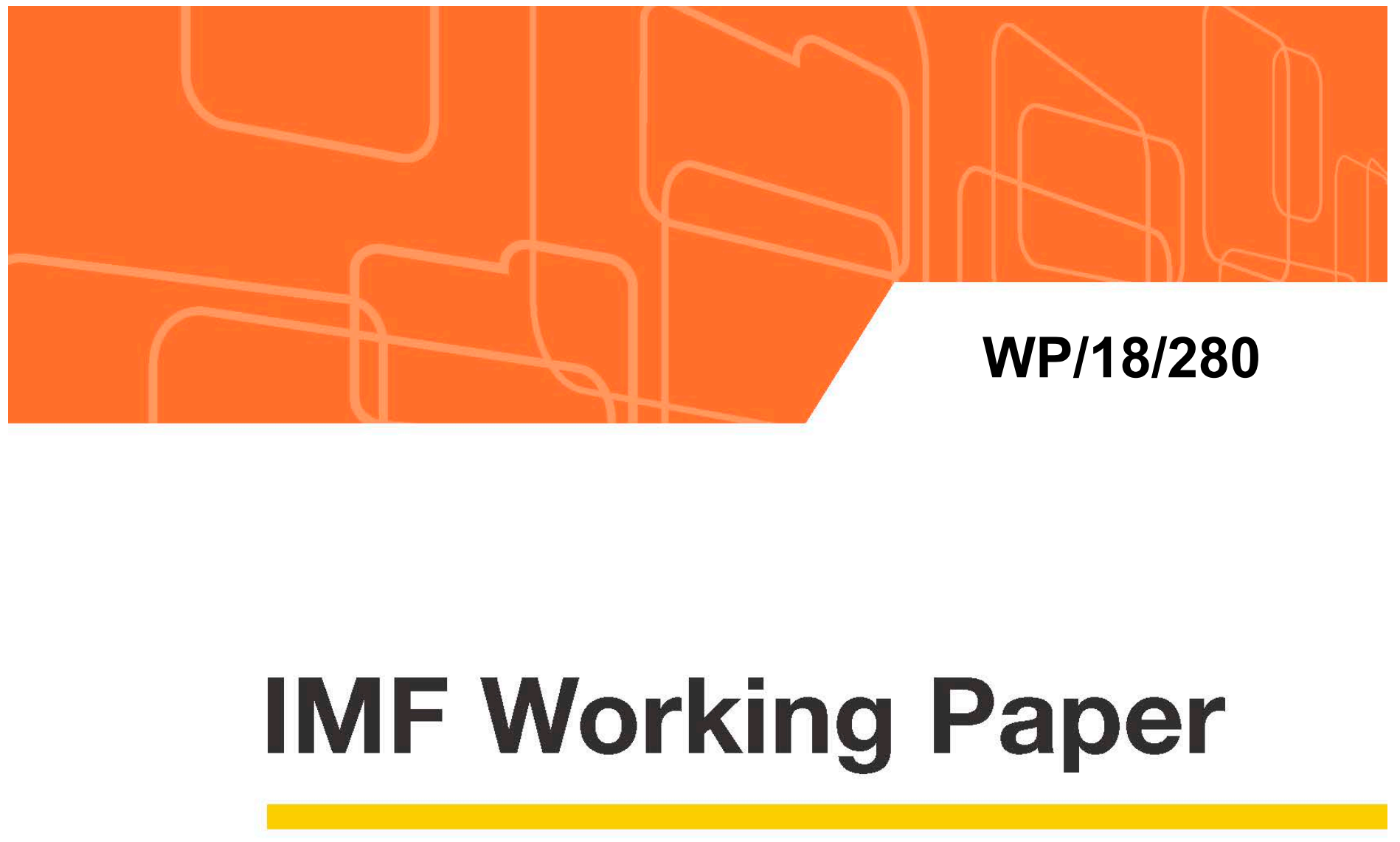

\title{
Expectations' Anchoring and Inflation Persistence
}

\author{
by Rudolfs Bems, Francesca Caselli, Francesco \\ Grigoli, Bertrand Gruss, and Weichen Lian
}

IMF Working Papers describe research in progress by the author(s) and are published to elicit comments and to encourage debate. The views expressed in IMF Working Papers are those of the author(s) and do not necessarily represent the views of the IMF, its Executive Board, or IMF management.
| N T E R N A T | O N A L
$M O N E T A R Y$
F U N D 


\title{
Expectations' Anchoring and Inflation Persistence*
}

\author{
Rudolfs Bems $^{\dagger} \quad$ Francesca Caselli ${ }^{\ddagger} \quad$ Francesco Grigoli ${ }^{\S}$ Bertrand Gruss ${ }^{\natural}$ \\ Weicheng Lian"
}

\begin{abstract}
Understanding the sources of inflation persistence is crucial for monetary policy. This paper provides an empirical assessment of the influence of inflation expectations' anchoring on the persistence of inflation. We construct a novel index of inflation expectations' anchoring using survey-based inflation forecasts for 45 economies starting in 1989 . We then study the response of consumer prices to terms-of-trade shocks for countries with flexible exchange rates. We find that these shocks have a significant and persistent effect on consumer price inflation when expectations are poorly anchored. By contrast, inflation reacts by less and returns quickly to its pre-shock level when expectations are strongly anchored.
\end{abstract}

Keywords: Anchoring, credibility, inflation expectations, inflation persistence, terms of trade.

JEL Codes: E31, E52.

\footnotetext{
*The views expressed in this Working Paper are those of the authors and do not necessarily represent those of the IMF or IMF policy. Working Papers describe research in progress by the authors and are published to elicit comments and to encourage debate. We thank, without implicating, Oya Celasun, Gabriel Di Bella, Raphael Espinoza, Douglas Laxton, Gian Maria Milesi-Ferretti, Mirjana Miletic, Maury Obstfeld, Rafael Portillo, Jay Shambaugh, and Philippe Wingender for their comments and suggestions. Jungjin Lee and Jilun Xing provided excellent research assistance.

$\dagger$ International Monetary Fund, Research Department, rbems@imf.org.

${ }^{\ddagger}$ International Monetary Fund, Research Department, fcaselli@imf.org.

§International Monetary Fund, Research Department, fgrigoli@imf.org.

『International Monetary Fund, Research Department, bgruss@imf.org.

"International Monetary Fund, Research Department, wlian@imf.org.
} 


\section{Contents}

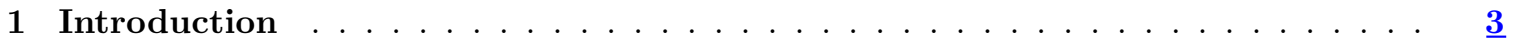

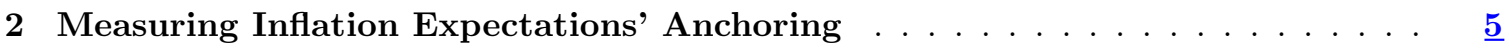

2.1 Data . . . . . . . . . . . . . . . . . . . 5

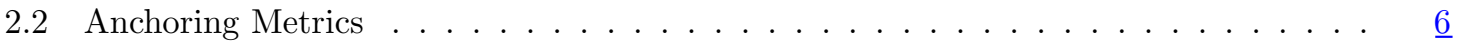

2.3 A Summary Anchoring Index . . . . . . . . . . . . . . . . . $\underline{7}$

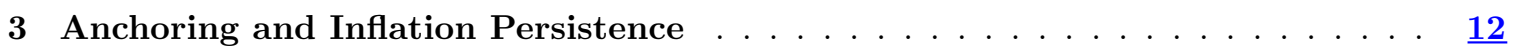

3.1 Terms-of-Trade Shocks . . . . . . . . . . . . . . . . . . . . . . . $\underline{13}$

3.2 Empirical Approach and Main Results . . . . . . . . . . . . . . . . . $\underline{15}$

3.3 Exchange Rate Depreciation and Pass-Through . . . . . . . . . . . . . $\underline{19}$

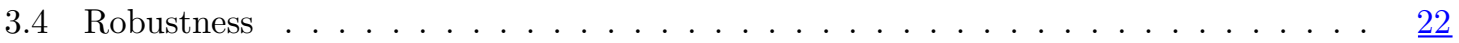

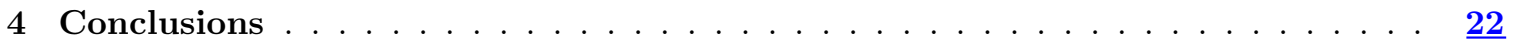

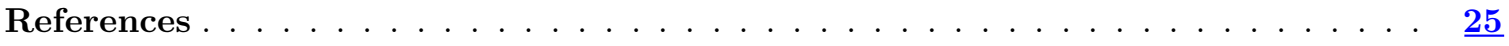

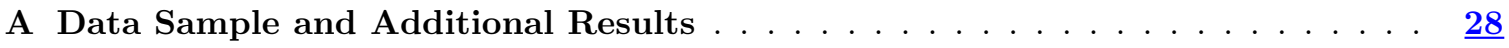

\section{List of Figures}

\begin{tabular}{|c|c|}
\hline & \\
\hline dex of Inflation Expectations' Anchoring, 1998-2017 & \\
\hline tribution of the Index of Inflation Expectations' Anchoring. & \\
\hline dex of Inflation Expectations' Anchoring-Cross-Country Heterogeneity & \\
\hline horing and Country Characteristics, 1989-2017 & \\
\hline on of Commodity Terms-of-Trade Shocks & \\
\hline esponse of Consumer Prices to a Terms-of-Trade Shock, by Exchange Rate Regime & \\
\hline loats & \\
\hline Trade Shock, by Anchoring & \\
\hline hs, by Anchoring & \\
\hline horing & \\
\hline by Anchoring & \\
\hline de Shock, by & \\
\hline & \\
\hline Rate after 6 Months, by Anchoring & \\
\hline nse of Consumer Prices & \\
\hline sts-Data Availability & \\
\hline & \\
\hline
\end{tabular}

\section{List of Tables}

A.1 Mean and Standard Deviation of Long-Term Inflation Forecasts Data Availability Page

A.2 Cumulative Response of Consumer Prices-Estimation Results . . . . . . . . . . $\frac{28}{30}$

A.3 Response of Consumer Price Inflation-Estimation Results . . . . . . . . . . $\underline{\underline{30}}$ 
"With expectations of inflation anchored, any given shock to inflation-whether it is from aggregate demand, energy prices, or the foreign exchange rate-will have a smaller effect on expected inflation and hence on trend inflation. These shocks will then have a much less persistent effect on actual inflation."

-Mishkin (2007)

\section{Introduction}

Theory indicates that the persistence of inflation in response to temporary shocks is affected not only by intrinsic factors, such as the extent to which price setters index prices to past inflation, but also by how monetary policy is conducted and how credible it is (Fuhrer, 2010). ${ }^{1}$ While the credibility of monetary policy is not directly observable, it is reflected in the extent to which the public's long-term inflation expectations are anchored (King, 1995). Indeed, the decline in inflation persistence in the United States is often attributed to an improvement in expectations' anchoring (e.g., Williams, 2006; Bernanke, 2007; Mishkin, 2007). Alogoskoufis and Smith (1991) argue that low inflation persistence is achieved through some form of credible commitment. They show that the gold standard served this purpose in the past, and argue that an alternative is central bank independence together with monetary institutions that put a lot of weight on price stability. More recently, Benati (2008) finds that inflation persistence in a sample of advanced economies is related to the monetary regime in place. Yet, despite the importance attributed to expectations' anchoring for inflation dynamics, there is little systematic cross-country evidence on the evolution and cross-sectional differences in inflation expectations' anchoring and its impact on inflation persistence.

This paper documents the extent of anchoring of inflation expectations in a large sample of economies and explores whether it affects the persistence of the inflationary process. Drawing from the literature (Capistrán and Ramos-Francia, 2010; Dovern et al., 2012; Demertzis et al., 2012), we use survey-based measures of long-term inflation forecasts from professional analysts in 45 advanced and emerging economies since 1989 to construct four complementary metrics of anchoring of inflation expectations: ${ }^{2}$ (i) a measure of absolute deviations in inflation forecasts from a target; (ii) a measure of the variability of inflation forecasts over time; (iii) the dispersion of inflation forecasts across individual forecasters; and (iv) the sensitivity of inflation forecasts to surprises about current inflation. We then combine these four metrics in a summary index that is comparable across countries.

Our index shows that the extent of anchoring of inflation expectations improved significantly over the past few decades, especially among emerging economies. Despite this large improvement, there is still substantial cross-country heterogeneity. The varying extent of anchoring in our sample is related to actual inflation performance - such as whether actual inflation is systematically above or below target - as well as to macroeconomic factors that the literature identifies as relevant for the behavior of inflation expectations. For instance, we find that anchoring is positively related to the transparency of monetary policy and the maturity of inflation targeting regimes, and to

\footnotetext{
${ }^{1}$ Central banks can choose among a wide set of monetary frameworks, but their ability to deliver price stability is ultimately determined by their credibility (Mishkin and Savastano, 2001; Woodford, 2005).

${ }^{2}$ We focus on long-term inflation forecasts - that is, three years ahead and beyond-reported by Consensus Economics surveys that should not reflect the effect of transitory shocks and the response of monetary policy. While alternative sources of long-term inflation forecasts exist for some countries (e.g., surveys conducted by Central Banks), the Consensus Economics database offers wider country and time coverage, and ensures consistency in the construction of surveys across countries.
} 
proxies for fiscal sustainability and institutions that reinforce sustainability (such as the maturity of fiscal rules). These findings lend support to the overall coherence of our anchoring index.

We then test whether the persistence of inflation dynamics is related to the extent of anchoring of inflation expectations by studying the response of consumer prices to well-identified external shocks under varying degrees of anchoring. More precisely, we estimate the response of consumer prices to terms-of-trade shocks using local projection methods (Jordà, 2005). Shocks to the terms of trade are identified with changes to country-specific commodity terms of trade indices from Gruss (2014), which are based on international prices and are arguably exogenous to domestic developments (Chen and Rogoff, 2003; Ricci et al., 2013; Fernández et al., 2017). ${ }^{3}$ To disentangle how the persistence of inflation relates to anchoring, we compare the response of consumer prices to a negative terms-of-trade shock under varying degrees of anchoring. Since the transmission of these shocks to consumer prices would differ depending on whether the exchange can adjust or not, we condition on the exchange rate regime and focus on nonpegs.

The change in relative prices following a terms-of-trade shock is expected to be reflected in consumer price inflation for some time after the shock in the presence of nominal rigidities. But we find that the dynamics of inflation are systematically different depending on how well anchored inflation expectations are. More precisely, negative terms-of-trade shocks lead to a persistent increase in consumer price inflation when expectations are poorly anchored-when the anchoring index takes a value corresponding to the $25^{\text {th }}$ percentile of the sample distribution. Inflation also increases somewhat when inflation expectations are anchored - that is, when the anchoring index is equal to the $75^{\text {th }}$ percentile of the sample distribution-but the response of inflation is much smaller and returns quickly to its pre-shock level. Our findings suggest that the difference in inflation dynamics between economies with poorly- and strongly-anchored expectations is only partly due to differences in the extent of exchange rate depreciation.

This paper is related to the literature on inflation persistence (see Fuhrer, 2010 for a survey), and especially to empirical studies documenting differences across countries and time (e.g., Alogoskoufis and Smith, 1991; Levin and Piger, 2004; Cogley and Sargent, 2005; Pivetta and Reis, 2007; Cogley and Sbordone, 2008; Cogley et al., 2010). The closest paper to ours is Benati (2008), who analyzes the relationship between post-WWII inflation persistence and the monetary regime in a sample of advanced economies - Canada, Japan, New Zealand, Sweden, Switzerland, the United Kingdom, the United States, the Euro area, and its largest countries (France, Germany, and Italy). He finds low or null serial correlation of inflation under inflation targeting, the gold standard, and in the European Monetary Union; and argues that under regimes with clearly defined nominal anchors inflation appears to be purely forward-looking. However, there is substantial heterogeneity in the quality of monetary policy within a given regime. ${ }^{4}$ We contribute to this literature by testing explicitly the role of anchoring of inflation expectations in affecting inflation persistence on a large sample that includes both advanced and emerging economies. Rather than estimating a measure of reduced-form persistence, which can be subject to substantial uncertainty (see, for instance, Pivetta and Reis, 2007 and Cogley et al., 2010), we exploit the variability in the degree of anchoring to assess the differences in the response of inflation to external shocks. Our paper is also related to studies that explore the extent of anchoring of inflation expectations (e.g., Kumar et al., 2015; Demertzis et al., 2012; Ehrmann, 2015; Kose et al., 2018). We contribute to this strand of the literature by providing four complementary metrics of anchoring of inflation expectations and a summary index using consistent data and methodology across a large sample of ad-

\footnotetext{
${ }^{3}$ The change in the international price of 46 commodities is weighted by the ratio of net exports of each commodity to GDP. The commodity terms of trade index provides an estimate of the changes in disposable income, relative to GDP, arising from fluctuations in commodity prices.

${ }^{4}$ See, for instance, evidence on the variability of transparency of monetary policy within inflation targeters in Brito et al. (2018).
} 
vanced and emerging economies.

The rest of the paper is organized as follows. Section 2 presents our metric for capturing the extent of anchoring of inflation expectations, documents how it varies across countries and over time, and how it is related to country characteristics. Section 3 explores how the extent of anchoring affects the persistence of inflationary shocks. Finally, Section 4 concludes and draws implications.

\section{Measuring Inflation Expectations' Anchoring}

The concept of anchored inflation expectations has no widely agreed-upon definition. The literature, however, identified a set of predictions about the behavior of inflation forecasts in economies that feature a strong nominal anchor. Under those circumstances, expectations for inflation over a sufficiently long horizon should be centered around the explicit or implicit target and hence not react to transitory fluctuations in actual inflation or in short-term inflation expectations (Bernanke, 2007; Demertzis et al., 2012; Kumar et al., 2015). Similarly, revisions of long-term forecasts should be minor (ibid.), so the average of long-term forecasts should be stable over time. In addition, if the monetary framework is credible and inflation expectations are well anchored, the dispersion (range of values) of individual long-term inflation forecasts should be low (Capistrán and RamosFrancia, 2010; Dovern et al., 2012; Ehrmann, 2015; Kumar et al., 2015).

Building on these operational characteristics, we first use survey-based long-term inflation forecasts from professional forecasters to construct a set of complementary metrics aimed at capturing the extent of anchoring of inflation expectations at the country level. We then construct a country-specific index summarizing the information of the four anchoring metrics.

\section{$2.1 \quad$ Data}

\section{Inflation Expectations}

We focus on the public's expectations about consumer price inflation over the medium- to longterm. Inflation expectations are captured by survey-based inflation forecasts from professional forecasters reported by Consensus Economics for horizons between three and seven years ahead. ${ }^{5}$ Focusing on horizons three years ahead and beyond ensures that beliefs about inflation in the long term are captured - rather than the effect of transitory shocks and the response of monetary policy.

For each period $t$ in which there is a survey and forecast horizon $h$, we use two moments of the distribution of responses by individual forecasters $j$ : (i) the average of individual inflation forecasts, $\pi_{t}^{e, h}=\frac{1}{T} \sum_{t=1}^{T} \pi_{j, t}^{e, h}$; and (ii) the standard deviation across individual forecasts, $\sigma_{t}\left(\pi_{j}^{e, h}\right)$.

Long-term inflation surveys by Consensus Economics are available at biannual frequency up to 2013 and quarterly thereafter. The data covers 24 advanced and 21 emerging economies but is unbalanced, starting between 1989 and the early-1990s for most countries, but only since 2009 in a few cases. ${ }^{6}$

\footnotetext{
${ }^{5}$ The one-year-ahead horizon in any given Consensus survey corresponds to forecasts for the current calendar year, the two-year-ahead horizon corresponds to the following calendar year, and so forth. The horizon of seven years ahead and beyond is the longest available.

${ }^{6}$ Income classifications are according to the IMF World Economic Outlook database and as of October 2018.
} 


\section{Inflation Target}

Some of the anchoring metrics we propose below require a value for the inflation target at each forecast horizon. For economies that adopted an inflation-targeting regime, the inflation targets at each point in time for the current current year and up to seven years ahead are retrieved from published central bank inflation reports. When a single target is announced, it is assumed that the target refers to the objective for the current year as well as for all subsequent years. When a target is announced for the current year and the long term but without an explicit path for the intermediate targets (i.e., between the current year and the long-term), the assumption is that the long-term target corresponds to the inflation target three years after the last explicit shortterm target. For economies that do not follow inflation-targeting regimes, the inflation target at all horizons is set to the mean inflation forecast for the longest-term horizon, $\pi_{t}^{e, 7+}$.

\subsection{Anchoring Metrics}

We start by constructing four country-specific metrics aimed at capturing the extent of anchoring of inflation expectations at horizon $h$ over a given period $\omega$ :

- Metric \#1 - Deviation of long-term mean inflation forecasts from target. If inflation expectations are well anchored, beliefs about future inflation should be, on average, close to the inflation target pursued by the monetary authority (Demertzis et al., 2012; Kumar et al., 2015). The root-mean-square deviation of the mean inflation forecast at horizon $h$ from the inflation target over period $\omega$ is given by

$$
\sqrt{\frac{1}{T} \sum_{t=1}^{T}\left(\pi_{t}^{e, h}-\pi_{t}^{*}\right)^{2}}, \text { with } h=3, \ldots, 7 ; t \in \omega
$$

in which $\pi^{*}$ is the central bank's inflation target for inflation-targeting economies or the oneyear moving average of 10-year-ahead inflation forecasts $\left(\pi_{t}^{e, 10}\right)$ otherwise.

- Metric \#2 - Variability of mean long-term inflation forecasts. If inflation expectations are well anchored, revisions of agents' long-term forecasts should be small, and thus the average forecast relatively stable over time (ibid.). The standard deviation of the mean inflation forecast at horizon $h$ over period $\omega$ is given by

$$
\sqrt{\frac{1}{T-1} \sum_{t=1}^{T}\left(\pi_{t}^{e, h}-\overline{\pi^{e, h}}\right)^{2}}, \text { with } h=3, \ldots, 7 ; t \in \omega
$$

in which $\overline{\pi^{e, h}}$ is the average of mean inflation forecasts over period $\omega$.

- Metric \#3 - Dispersion of long-term inflation forecasts. Individual beliefs about long-term inflation should be close to each other if expectations are well-anchored - and would coincide if they are perfectly anchored (Capistrán and Ramos-Francia, 2010; Dovern et al., 2012; Ehrmann, 2015; Kumar et al., 2015). The dispersion of forecasts is captured by the standard

Early Consensus Economics' surveys only report mean forecasts; the dispersion of responses is only available since 2005, or even later in a few cases. Data availability on long-term inflation forecasts is summarized in Figure A.1 and Table A.1. 
deviation of $h$-year-ahead inflation forecasts of individual forecasters at each period $t$, averaged over period $\omega$ :

$$
\frac{1}{T} \sum_{t=1}^{T}\left[\sqrt{\frac{1}{J-1} \sum_{j=1}^{J}\left(\pi_{j, t}^{e, h}-\pi_{t}^{e, h}\right)^{2}}\right], \text { with } h=3, \ldots, 7 ; t \in \omega
$$

in which $\pi_{j, t}^{e, h}$ denotes the inflation forecast of forecaster $j$ at time $t$ for horizon $h$ and $\pi_{t}^{e, h}$ is the average across forecasters.

- Metric \#4 - Sensitivity of long-term inflation forecasts to inflation surprises. Under wellanchored expectations, there should be little comovement between long-term inflation expectations and short-term inflation expectations, which would capture inflation surprises (Ehrmann, 2015; Kumar et al., 2015). The sensitivity of $h$-year-ahead inflation forecasts to short-term forecasts, $\beta^{h}$, is obtained by estimating the following country-specific regressions over period $\omega$ :

$$
\Delta \pi_{t}^{e, h}=\alpha+\beta^{h} \Delta \pi_{t}^{e, 1}+\epsilon_{t}, \text { with } h=3, \ldots, 7 ; t \in \omega
$$

in which $\Delta \pi_{t}^{e, 1}$ and $\Delta \pi_{t}^{e, h}$ denote the change in mean inflation forecasts for the short term (that is, for the current year) and for $h$ years ahead, respectively, between surveys at $t-1$ and $t$.

These measures are computed for each forecast horizon from three- to seven-year-ahead inflation forecasts. While Metric \#1 and Metric \#3 can be computed for each period $t$ in which a survey is available, a minimum number of surveys is needed to compute Metric \#2 and Metric \#4. In the analysis that follows, we set those minimum numbers of surveys at 4 and 10, respectively. Annex Figure A.2 shows the cross-country distribution of anchoring based on three-year-ahead inflation expectations for a balanced panel of economies with data available since 1998.

The four metrics we propose are complementary, with advantages and shortcomings - including in terms of data coverage - and no single metric may fully capture the extent of anchoring. For instance, if long-term expectations are well-coordinated and stable around a level above the central bank's objective and do not react to short-term inflation surprises, one may argue that the economy has a strong nominal anchor. This would be reflected in relatively good readings in Metric \#2 through Metric \#4, although Metric \#1 would score relatively bad. Similarly, if long-term expectations are stable around the target on average, but there is substantial disagreement across individual forecasters, the good reading in Metric \#1, Metric \#2, and Metric \#4 would stand in contrast with a bad score under Metric \#3.

\subsection{A Summary Anchoring Index}

The four anchoring metrics presented above capture distinctive characteristics of the behavior of inflation expectations, but they tend to convey a consistent picture (Figure 1). For instance, the correlation between the relative ranking of countries across any two of the anchoring measures based on three-year-ahead inflation forecasts ranges from 0.56 to 0.87 .

We construct a country-specific index summarizing the information of the four anchoring metrics as follows. For each metric $m$ based on $h$-years ahead inflation expectations $x_{i, \omega}^{m, h}$, where $i$ de- 
notes countries and $\omega$ denotes periods (rolling windows), we first construct a standardized measure $z_{i, \omega}^{m, h}=\left(x_{i, \omega}^{m, h}-\bar{x}^{m, h}\right) / \sigma\left(x^{m, h}\right)$, where $\bar{x}^{m, h}$ and $\sigma\left(x^{m, h}\right)$ denote the average and standard deviation of metric $m$ (at horizon $h$ ) across all countries and periods between 1989 and 2017. Observations for each standardized metric will then be centered around zero, with a standard deviation of one. The anchoring index for horizon $h$ is then constructed as minus the simple average of the four standardized metrics $\left(z_{i, \omega}^{m, h}\right)$, so that a higher (lower) value of the index corresponds to a better (worse) anchoring of inflation expectations. In the analysis that follows, we focus on the index using three-year ahead inflation forecasts, but we consider longer horizons in robustness exercises (section 3.4).

Figure 1: Alternative Anchoring Metrics

(Ranking of countries, average over 2004-17)

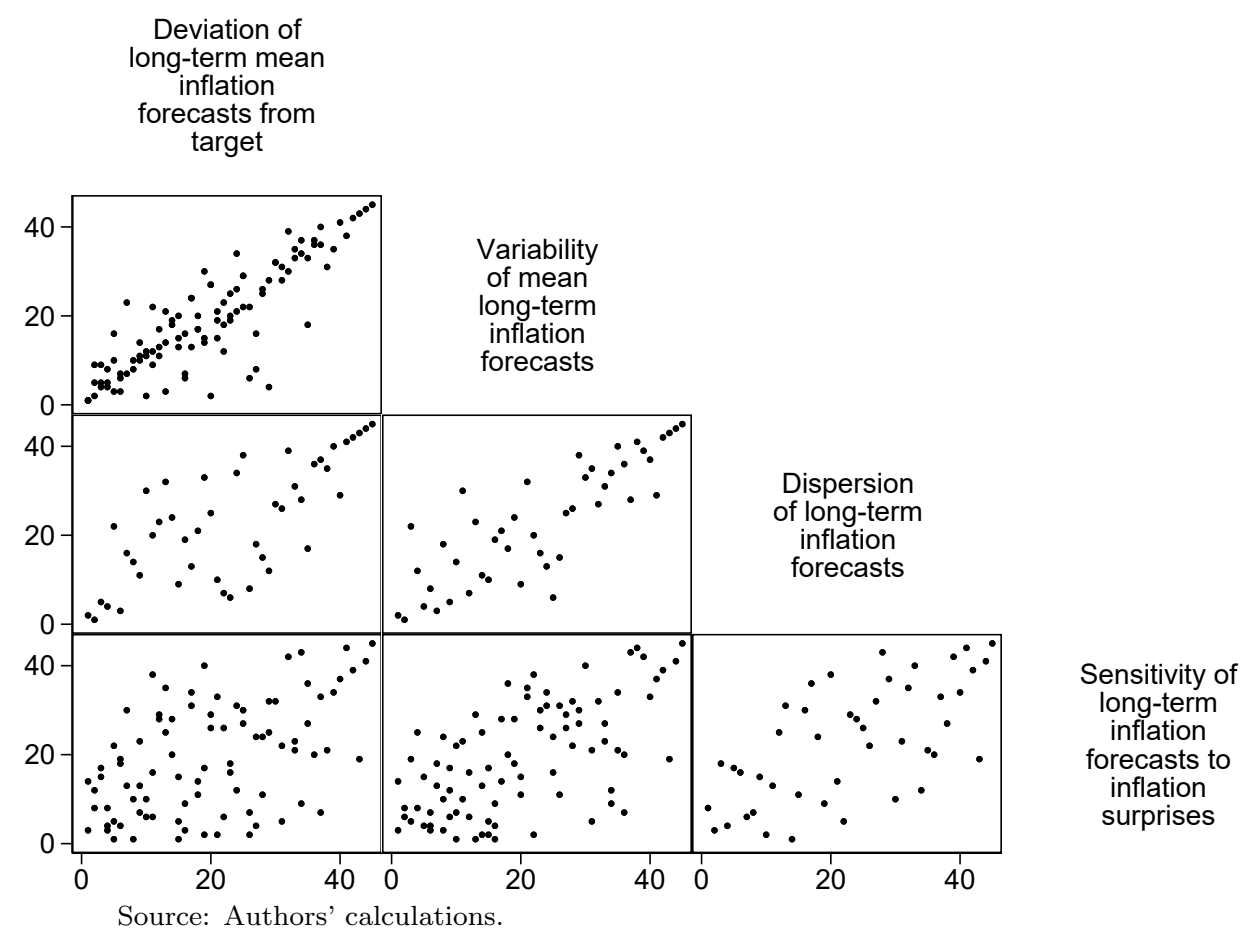

Figure 2 shows the evolution of the anchoring index based on three-year ahead inflation expectations for a balanced sample of economies with data available since 1998. The extent of anchoring increased substantially over the sample period. While the upper decile of the distribution remained broadly stable at a value of about 0.5 (Figure 2, panel (a)), the bottom decile increased from about -1.5 in the first subperiod (1998-2003) to above zero at the end of the sample (201217). The median across countries increased much less - from slightly below zero to about 0.3 over the sample period.

The lion's share of the improvement in anchoring happened among emerging economies, and primarily up to the mid-2000s (Figure 2, panel (b)). Subsequent gains have been rather subdued. The median anchoring across advanced economies was relatively stable over the past two decades, although the interquartile range narrowed during the 2000s as a result of improvements at the lower quartile of the distribution. The much larger improvement in anchoring in emerging than in advanced economies is also evident when comparing the cross-country distribution at the beginning and the end of the sample (Figure 3). 
Figure 2: Index of Inflation Expectations' Anchoring, 1998-2017

(Three-Year-Ahead Inflation Expectations)

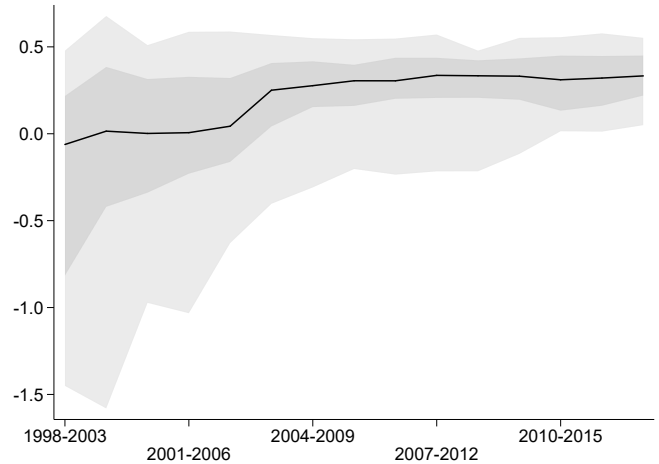

(a) All economies

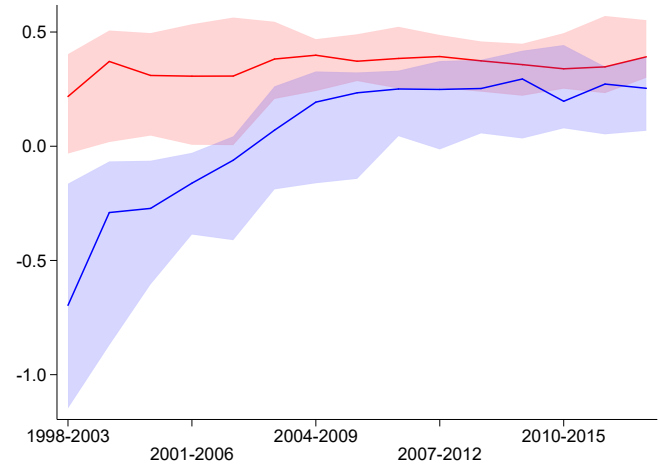

(b) Advanced (red) and emerging (blue) economies

Source: Authors' calculations.

Note: The figures show the evolution of the anchoring index computed over six-year rolling windows for a balanced panel of countries with data available since 1998. The lines denote the median across countries. In panel (a), the (light) dark shaded areas denote (interdecile) interquartile ranges. In panel (b), the shaded areas denote interquartile ranges.

Figure 3: Distribution of the Index of Inflation Expectations' Anchoring

(Percent; Solid line for 1998-2003, dashed line for 2012-2017))

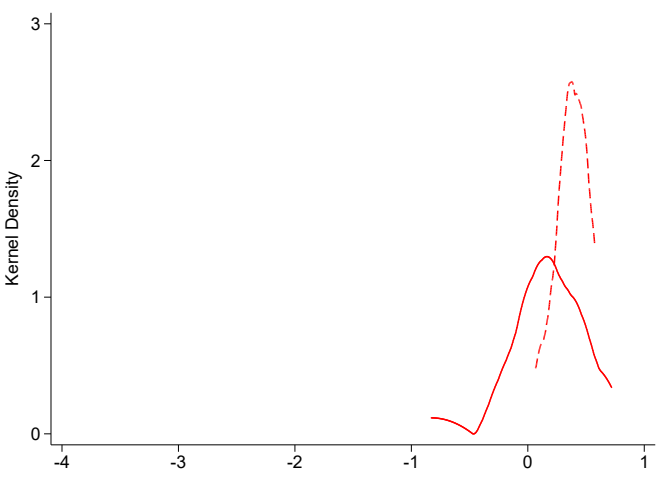

(a) Advanced economies

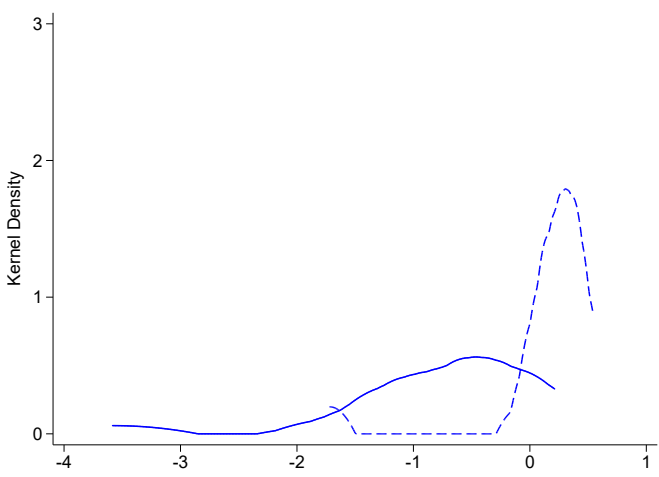

(b) Emerging economies

Source: Authors' calculations.

Note: Excludes observations below/above the $1^{\text {st }} / 99^{\text {th }}$ percentile.

Despite the large improvement in anchoring registered by several economies, substantial variation persists. Figure 4 shows the average value of the anchoring index for each country in the sample during 2004-17, when anchoring was broadly stable both among advanced and emerging economies. The evidence shows that there is significant cross-country heterogeneity in the value of the anchoring index, especially among emerging economies. While on average anchoring in these economies is weaker than in the advanced economies, the level of anchoring in some countries (e.g., Chile and Poland) was even higher than the average for advanced economies. But for the emerging economies at the bottom of the distribution (e.g., Argentina, Ukraine, and Russia) the index value is substantially lower. 
Figure 4: Index of Inflation Expectations' Anchoring - Cross-Country Heterogeneity

(Average over 2004-17)

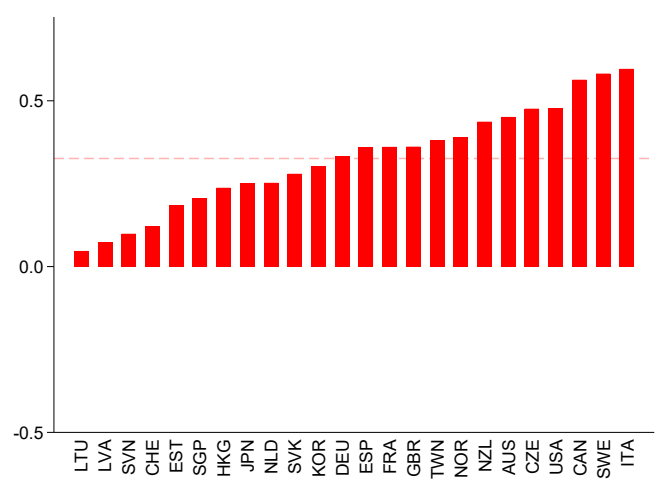

(a) Advanced economies

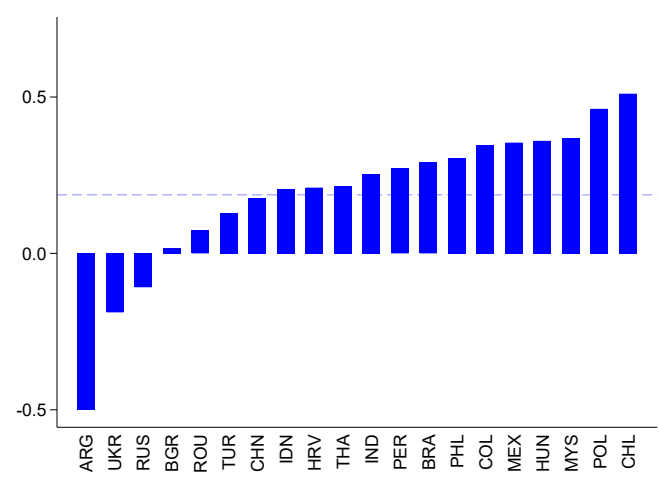

(b) Emerging economies

Source: Authors' calculations.

Note: The red (blue) dashed line denotes the average across advanced (emerging) economies. The value for Argentina is -1.5 , but we set the minimum of the vertical axis to -0.5 to ease visualization.

The varying extent of anchoring in our sample could reflect differences in actual inflation performance. While it is normal for inflation to temporarily deviate from the inflation objective as the economy is hit by shocks and monetary policy operates with lags, long-term expectations could become unanchored if actual inflation is systematically above or below the target. Indeed, the evidence points to a strong nonlinear relationship between the anchoring index and the percent of time that actual inflation is above its target (Figure 5, panel [a]). The highest anchoring levels in the sample are observed when actual inflation was higher than the target only half of the time.

The degree of anchoring also appears related to some fundamental macroeconomic factors that earlier studies found relevant for the behavior of inflation expectations. The literature suggests that the extent of anchoring is intimately related to the credibility of monetary policy (Cukierman and Meltzer, 1986; King, 1995). ${ }^{7}$ A monetary policy plan will be credible if the public believes the monetary authority does not have incentives to deviate from that plan or does not need to subordinate it to other considerations, such as restoring fiscal solvency. The formation of inflation expectations thus lies at the heart of any concept of credibility. Central banks may use monetary policy to pursue multiple goals, but the credibility of the policy is typically interpreted in terms of inflation performance.

Several studies found that certain characteristics of the monetary framework, including adopting an inflation target and transparent public communication of monetary policy, help anchor inflation expectations. Levin et al. (2004) and Gürkaynak et al. (2010) find that announcing an explicit inflation target helped anchoring long-term inflation expectations in advanced economies. Capistrán and Ramos-Francia (2010) find that the dispersion of inflation forecasts in emerging economies tended to fall after adopting inflation targeting, while Brito et al. (2018) show that the reduction in disagreement that follows the adoption of inflation targeting is largely due to increased central bank transparency. IMF (2018) finds that stronger transparency frameworks and communication strategies are associated with more-anchored inflation expectations.

\footnotetext{
${ }^{7}$ Cukierman and Meltzer (1986) argue that the ability of the monetary authority to achieve its future objectives depends on the inflation expectations of the public, which in turn depend on the public's perception of the credibility of the monetary authority.
} 
Figure 5: Anchoring and Country Characteristics, 1989-2017

(Three-Year-Ahead Inflation Expectations)

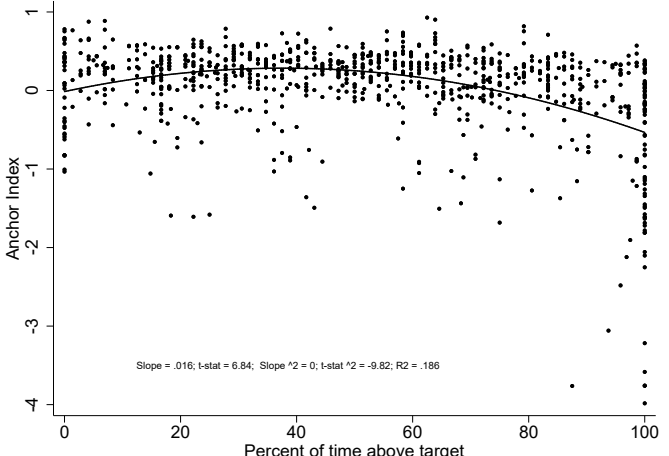

(a) Inflation performance

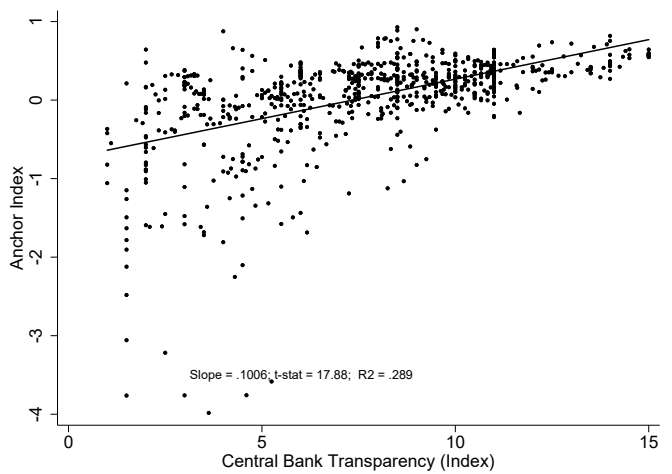

(c) Central Bank transparency

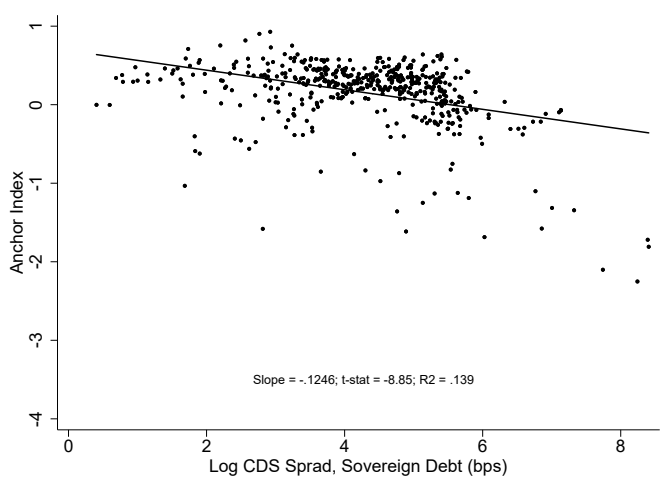

(e) Fiscal sustainability

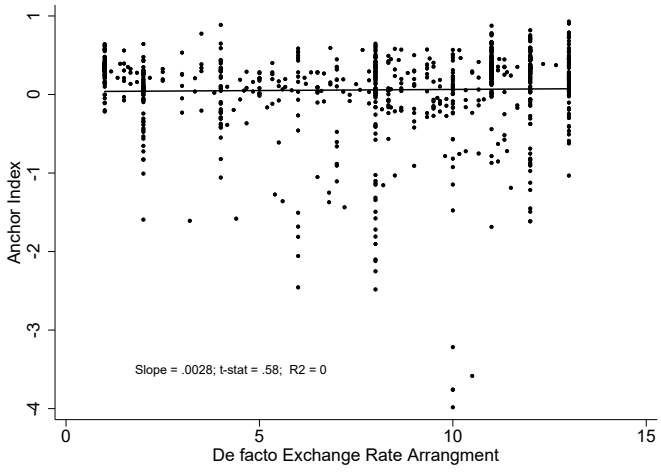

(b) Exchange rate regime

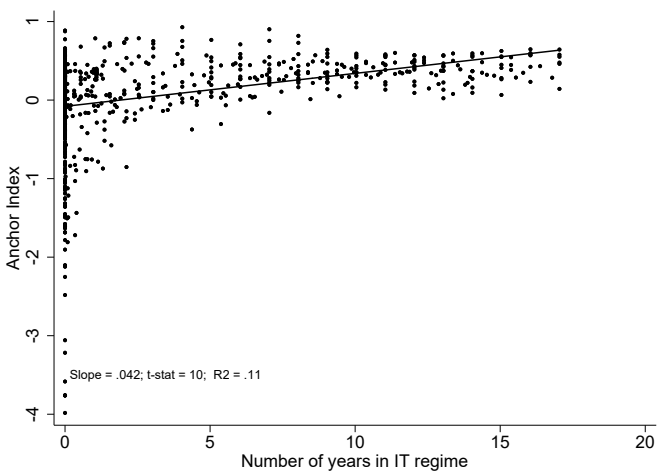

(d) Maturity of inflation targeting regime

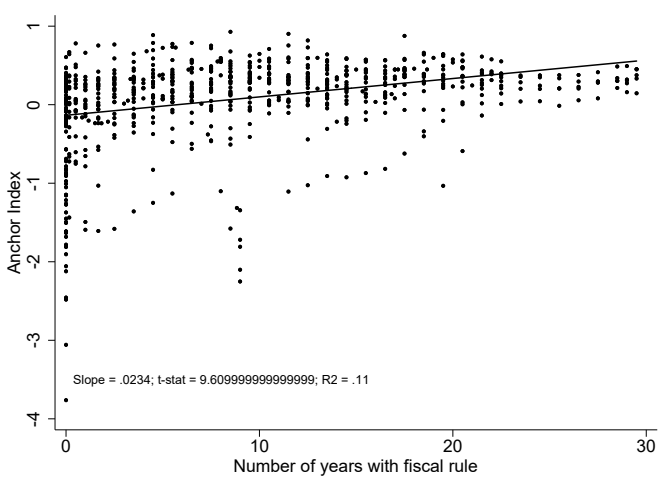

(f) Maturity of fiscal rule

Source: Authors' calculations.

Note: Each observation corresponds to the average for a given country over a 6 -year rolling window. IT $=$ inflation targeting.

Our analysis suggests there is no evidence of a significant association between anchoring and the exchange rate regime - as measured by Ilzetzki et al. (2017) de facto regime classification (Figure 
5, panel [a]). There are observations with strongly anchored expectations both for pegs (no separate legal tender or currency union; pre announced peg or currency board arrangement) and very flexible exchange regimes (managed floating; freely floating). However, the extent of anchoring in the sample does appear related to the transparency of central bank policy (as measured by Dincer and Eichengreen, 2014; Figure 5, panel [c]). Adopting an inflation targeting regime is closely associated with increased transparency. It implies, at a minimum, announcing an explicit target for inflation, but typically also other changes that improve the quantity and quality of information shared with the public. The evidence in Figure 5, panel (d), shows that, indeed, inflation expectations are better-anchored in countries that adopted an inflation targeting regime - and, more precisely, to the age of the regime.

Regardless of the specific design of the monetary framework, a sound and sustainable fiscal policy is essential for the credibility of monetary policy (see, for instance, Savastano et al., 1997, Mishkin, 2000, and Mishkin and Savastano, 2001). ${ }^{8}$ If public debt is perceived to be unsustainable, higher inflation will be expected. The mechanism for the expected price acceleration is the expectation of "fiscal dominance" - an eventual monetization of the debt or large devaluations of the currency. Some studies indeed found an association between fiscal institutions and credibility on the one hand and inflation performance and the anchoring of inflation expectations on the other (Combes et al., 2017; Montes, Acar, et al., 2018), or a link between expected fiscal performance and inflation expectations (Celasun et al., 2004).

In line with these studies, the cross-country variation in the degree of anchoring in the sample covered in this paper is positively related to the market perception about the sustainability of public debt as proxied by credit default swap (CDS) spreads for sovereign debt (Figure 5, panel $[\mathrm{e}]){ }^{9}$ The extent of anchoring is also related to whether a fiscal rule is in place and, in particular, to how long a fiscal rule has been in place (Figure 5, panel [f]).

While a comprehensive study of the determinants of inflation expectations' anchoring is beyond the scope of this paper, these findings lend support to the overall coherence of our anchoring index.

\section{Anchoring and Inflation Persistence}

Theory indicates that expected inflation is a key driving force of actual inflation (e.g., Galí and Gertler, 1999). If inflation expectations are well-anchored, inflationary shocks should have only temporary effects and inflation should exhibit low persistence (see discussion of the theoretical literature in Fuhrer, 2010). Alogoskoufis and Smith (1991) find that a credible lack of monetary accommodation is key for achieving low inflation persistence, and argue that this can be achieved through an independent central bank that puts a lot of weight on price stability. ${ }^{10}$ Benati (2008) shows that the persistence of inflation is affected by changes in the monetary regime and argues that is zero or very low under stable regimes with clearly defined nominal anchors. Bernanke (2007) and Mishkin (2007) argue that the improvement in the extent of anchoring of inflation expecta-

\footnotetext{
${ }^{8}$ Other factors are also likely to matter for longer-term anchoring; for instance, Mishkin and Savastano (2001) point to the importance of stringent prudential regulations and strict supervision of financial institutions to ensure that the system is capable of withstanding exchange rate fluctuations.

${ }^{9}$ The analysis uses asset prices (CDS spreads) to capture the market perception about the sustainability of public debt. Importantly, these measures incorporate not only concerns about the current level of public debt for intertemporal fiscal solvency, but also the expected path of future deficits.

${ }^{10}$ See Argov et al. (2007) and Alichi et al. (2009) for New Keynesian monetary models where the endogenous extent of central bank credibility affects inflation expectations and the propagation of inflationary shocks.
} 
tions in the United States led to a decline in the persistence of inflation dynamics.

Having documented a wide variation in the extent of anchoring of inflation expectations across countries and over time, this section explores how this heterogeneity relates to the persistence of inflationary shocks. In order to identify these shocks, we focus on the response of consumer prices to external shocks to the terms of trade, proxied with the variation in a country-specific commodity terms of trade index - as defined below.

\subsection{Terms-of-Trade Shocks}

A common challenge for analyzing empirically the effect of variations in the terms of trade is to identify exogenous shocks. Standard measures of terms of trade - the overall export-to-import price ratio - are affected by price rigidities and incomplete pass-through, making identification almost impossible (Chen and Rogoff, 2003). We follow an approach often adopted in the literature (Aizenman et al., 2012; Ricci et al., 2013; Fernández et al., 2017) that relies on country-specific commodity terms of trade indices based on international commodity prices. More precisely, we capture terms-of-trade shocks with the change in the natural logarithm of the commodity terms of trade index in Gruss (2014), which provides an estimate of the changes in disposable income, relative to GDP, arising from fluctuations in commodity prices:

$$
\Delta \text { ctot }_{i, t}=\sum_{c=1}^{C} \Delta P_{c, t} \cdot \Omega_{i, c, t}
$$

where $P_{c, t}$ is the logarithm of the real price (that is, in US dollars and divided by the IMF's unit value index for manufactured exports) of commodity $c$ in period $t$, with $c=1, \ldots, 46$; and $\Delta$ denotes first differences.

The weight of commodity $c$ in country $i, \Omega_{i, c, t}$ in equation (5), is time varying. An alternative approach is to use average trade flows over a few years to construct country-specific commodity price indices (e.g., Aghion et al., 2010; Ricci et al., 2013). One reason for using time-invariant weights is to ensure that the movement in the index is invariant to changes in import and export volumes in response to commodity price fluctuations. A drawback, however, is that the mix of traded commodities and the overall importance of net commodity exports in output changes significantly over time. The index we employ here uses time-varying weights to capture these changes, but the weights are lagged to address endogeneity concerns. ${ }^{11}$ More precisely, the weight of commodity $c$ in country $i$ for all monthly observations $t$ within year $\tau$ is given by:

$$
\Omega_{i, c, t}=\frac{1}{3} \sum_{s=1}^{3} \frac{x_{i, c, \tau-s}-m_{i, c, \tau-s}}{G D P_{i, \tau-s}},
$$

where $x_{i, c, \tau}\left(m_{i, c, \tau}\right)$ denotes the exports (imports) value of commodity $c$ of country $i$ in year $\tau$, expressed in US dollars; and $G D P_{i, \tau}$ denotes country $i$ 's nominal GDP is US dollars in year $\tau$. A one percentage point change in the commodity terms of trade index can thus be interpreted as a change in aggregate disposable income equivalent to one percentage point of GDP - providing a convenient cross-country normalization of the income effect associated with terms-of-trade shocks.

\footnotetext{
${ }^{11}$ Ancillary evidence available upon request shows that the results in the paper are robust to using time-invariant weights.
} 
For ease of interpretation, variations in ctot have been reversed, so that a positive change denotes a deterioration in the terms of trade. Figure 6 shows the distribution of commodity terms-of-trade shocks for the estimation sample. The distributions for both advanced and emerging economies are very similar, centered around zero, and with a standard deviation of slightly less than half percentage point.

Figure 6: Distribution of Commodity Terms-of-Trade Shocks

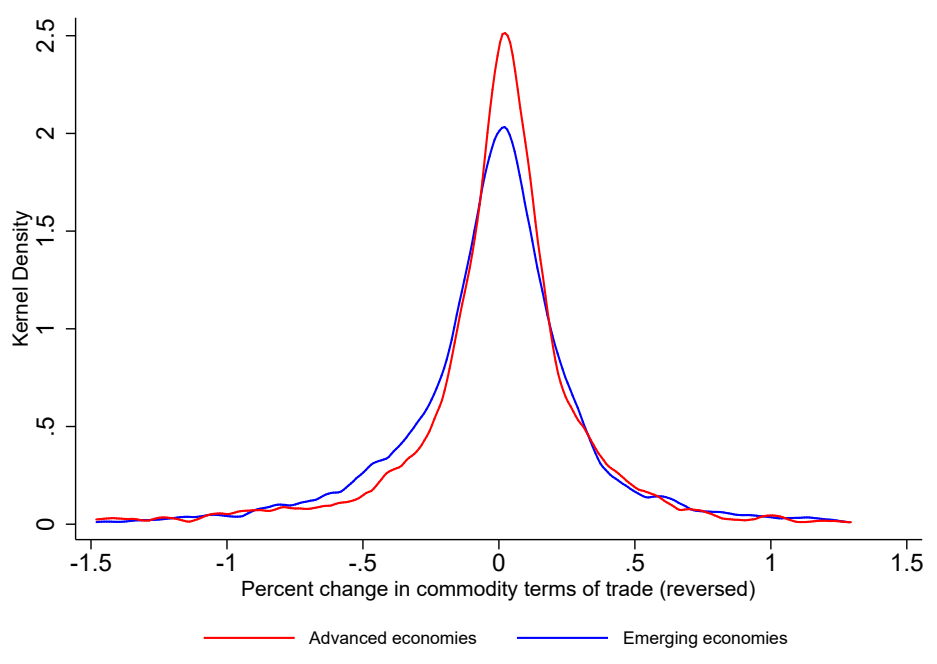

Source: Authors' calculations.

Note: The standard deviation for advanced (emerging) economies is $0.48(0.44)$. The figure excludes observations below/above the $1^{\text {st }} / 99^{\text {th }}$ percentile.

How do terms-of-trade shocks affect domestic consumer prices? Commodity terms of trade can affect domestic consumer prices through two channels, and their impact depends on whether the exchange rate can adjust. Consider, first, that the exchange rate does not adjust. The first channel is the direct effect from the change in international commodity prices on the domestic price of consumer goods. The effect through this channel is however ambiguous. An increase in the price of a given commodity, which would have a direct positive effect on consumer prices, can cause the commodity terms of trade to increase or decrease, depending on whether the country is a net exporter or net importer of that commodity. The direct effect also depends on the weight of that specific commodity in the consumption basket, which could be very low in some cases (e.g., for some metals).

The second channel is indirect and due to the income effect from the terms-of-trade shock. The direction of the effect is unambiguous. A negative terms-of-trade shock, for instance, would lead to a decline in aggregate disposable income. This, in turn, would imply subdued aggregate demand and put downward pressure on domestic consumer prices.

If the exchange rate can adjust, there would be an additional and important propagation mechanism. A deterioration in the commodity terms of trade, with a consequent negative income effect, would trigger a depreciation of the domestic currency. Regardless of the direct effect associated with the change in international prices (i.e., in US dollars) that moved the terms of trade, the exchange rate depreciation triggered by the shock would have an unambiguous inflationary impact on consumer prices expressed in domestic currency. 
In the analysis that follows, we thus condition the responses on the exchange rate regime and focus on the effect of anchoring within floats (i.e., under relatively flexible exchange rate regimes) where this channel is present. ${ }^{12}$ We want to assess whether the inflationary effect of a negative shock to the terms of trade that triggers a depreciation of the domestic currency is smaller and fades out quicker when inflation expectations are better anchored. To test this hypothesis we explore whether the cumulative response of consumer prices after a terms-of-trade shock depends on how well anchored inflation expectations were before the shock hit.

\subsection{Empirical Approach and Main Results}

We estimate the cumulative response of the consumer price index over 12 months to a change in the country-specific commodity terms of trade index in a panel setting using the local projection method of Jordà (2005). A key advantage of this approach is that it can easily accommodate nonlinearities in the impulse response functions and handle potential cross-country correlation in the error term (Auerbach and Gorodnichenko, 2012). Our baseline specification is as follows:

$$
\begin{aligned}
p_{i, t+h-1}-p_{i, t-1}=\alpha^{h} & +\beta_{1}^{h} \text { anchor }_{i, t}+\beta_{2}^{h} \text { flex }_{i, t}+\beta_{3}^{h} \Delta \text { ctot }_{i, t} \\
& +\beta_{4}^{h} \text { flex }_{i, t} \times \Delta \text { ctot }_{i, t}+\beta_{5}^{h} \text { anchor }_{i, t} \times \Delta \text { ctot }_{i, t} \\
& +\beta_{6}^{h} \text { flex }_{i, t} \times \text { anchor }_{i, t} \times \Delta \text { ctot }_{i, t}+\beta_{7}^{h} \text { flex }_{i, t} \times \text { anchor }_{i, t} \\
& +\sum_{j=1}^{J} \rho_{j}^{h} \Delta p_{i, t-j}+\mu_{i}^{h}+\nu_{t}^{h}+\epsilon_{i, t+h-1}, \text { with } h=1, \ldots, 12,
\end{aligned}
$$

where $p_{i, t}$ denotes the natural logarithm of the consumer price level in country $i$ in period $t ; ;^{13} \mu_{i}$ are country fixed effects; $\nu_{t}$ are time fixed effects; $\Delta$ denotes first difference; and $\epsilon_{i, t+h}$ is a random disturbance. anchor is the average value of the inflation expectations anchoring index described in section 2.3 over a rolling window that covers the preceding six years. flex is a dummy variable that takes a value of zero for fixed exchange rate regimes and a value of one otherwise, based on the exchange rate regime index of Ilzetzki et al. (2017). ${ }^{14}$ We include 12 lags of the change in consumer prices (i.e., $J=12$ ). ${ }^{15}$

The specification in (7) is estimated by ordinary least squares for each $h=1, \ldots, 12$ using data for 31 economies at monthly frequency over $1999 \mathrm{~m} 1-2017 \mathrm{~m} 12 .{ }^{16}$ Since the dependent variable is

\footnotetext{
${ }^{12}$ Anchoring can also be imperfect under fixed exchange rate regimes, especially if the commitment towards the regime is perceived to be weak. While that could be an interesting aspect to investigate, we focus on the effect that the credibility of monetary policy may have on inflation persistence among floats. See Alogoskoufis and Smith (1991) and Benati (2008) for evidence on persistence in fixed exchange rate arrangements.

${ }^{13}$ Consumer prices correspond to headline consumer price indices (CPI) at monthly frequency reported by national authorities and obtained from Haver Analytics.

${ }^{14}$ Observations with coarse classifications 1 and 2 were considered fixed exchange regimes (i.e., flex $=0$ ). These include: no separate legal tender; pre announced peg or currency board arrangement; pre announced horizontal band that is narrower than or equal to +/-2 percent; de facto peg; pre announced crawling peg; pre announced crawling band that is narrower than or equal to +/-2 percent; de facto crawling peg; de facto crawling band that is narrower than or equal to $+/-2$ percent. Observations with coarse classification codes 5 ("free falling") and 6 ("dual market in which parallel market data is missing") were excluded. Other classifications are considered floats (i.e., flex $=1$ ). In robustness exercises of section 3.4 we: (i) include also observations classified as "free falling" (coarse classification 5); and (ii) consider the de facto exchange rate regime classification of Shambaugh (2004).

${ }^{15}$ Adding lags of $\Delta$ ctot does not alter the results.

${ }^{16}$ We exclude euro area countries from the analysis since, at the individual level, they don't have an independent
} 
defined in cumulative terms - it measures the cumulative growth in prices between $t-1$ and $t+h-$ the estimate of $\beta^{h}$ is the cumulative impact of an innovation in the terms of trade on the CPI. Following Jordà et al. (2015), we use country-based cluster-robust standard errors to correct for potential serial correlation and heteroscedasticity. ${ }^{17}$

We argued before in favor of conditioning on the exchange rate regime and focusing on flexible arrangements since the transmission of terms-of-trade shocks to consumer prices differs depending on whether the exchange rate can react to the shock or not. So before studying the influence of anchoring on inflation persistence for floats, we first explore whether shocks to the terms of trade have a significant effect on consumer prices for flexible exchange rate regimes. To facilitate the interpretation of the results, it is useful to compute the conditional cumulative effect of a change in ctot on the CPI: ${ }^{18}$

$$
\frac{\delta\left(p_{i, t+h-1}-p_{i, t-1}\right)}{\delta \Delta \text { ctot }_{i, t}}=\beta_{3}^{h}+\beta_{4}^{h} \text { flex }_{i, t}+\beta_{5}^{h} \text { anchor }_{i, t}+\beta_{6}^{h} \text { flex }_{i, t} \times \text { anchor }_{i, t}, \text { with } h=1, \ldots, 12,
$$

Figure 7 shows the cumulative effect of a negative terms-of-trade shock for pegs $($ flex $=0)$ and floats $($ flex $=1)$ on CPI, with anchor evaluated at its average across countries and periods in the estimation sample. The results indicate that, indeed, a negative terms-of-trade shock leads to a significant increase in consumer prices in economies with flexible exchange rate regimes. Compared to the path of CPI in the absence of shocks, the price level increases steadily over the following 12 months. Instead, the response of consumer prices for pegs is statistically indistinguishable from zero.

Among floats, however, there is substantial variability in how well anchored inflation expectations are. Figure 8 shows that this is indeed the case both over the whole estimation sample (19982017, panel [a]) and over the more recent past (2012-17, panel b). Thus, we next turn to the main hypothesis we want to test: is the effect of a negative shock to the terms of trade on consumer price inflation less persistent when expectations are better anchored?

We start by exploring the response of the level of prices. Figure 9, panel (a), shows the cumulative response of the CPI for floats over 12 months following a negative terms-of-trade shock when: (i) expectations are strongly anchored (anchor $=75^{\text {th }}$ percentile of its sample distribution); and (ii) expectations are weakly anchored (anchor $=25^{\text {th }}$ percentile of its sample distribution). The results indicate that when inflation expectations are poorly anchored, a deterioration in the terms of trade associated with a drop in disposable income of one percent of GDP leads to a significant and persistent increase in consumer prices. The CPI increases by 0.35 percentage point after six months and 0.55 percentage point one year after the shock. Instead, when inflation expectations are strongly anchored, the cumulative response of consumer prices is indistinguishable from zero. The difference between the responses under weakly and strongly anchored expectations is statistically significant at the 95 percent confidence level (Figure 9, panel [b]).

Figure 10 provides an alternative way to visualize our result, focusing on the cumulative response

monetary authority. We also exclude Venezuela, which experienced hyperinflation during the sample period, and Ukraine, where inflation dynamics towards the end of the sample were influenced by its civil war.

${ }^{17}$ The Driscoll and Kraay (1998) procedure, that is also robust to cross-sectional dependence, is used in robustness exercises (section 3.4).

${ }^{18}$ The estimation results for all horizons $h$ are shown in Annex Table A.2. The estimated coefficient $\beta_{6}^{h}$ is negative - meaning that, for floats, better-anchored inflation expectations are associated with a smaller increase of consumer prices following a negative terms-of-trade shock-for all $h=1, \ldots, 12$ and statistically significant at the 99 percent confidence level. 
Figure 7: Response of Consumer Prices to a Terms-of-Trade Shock, by Exchange Rate Regime

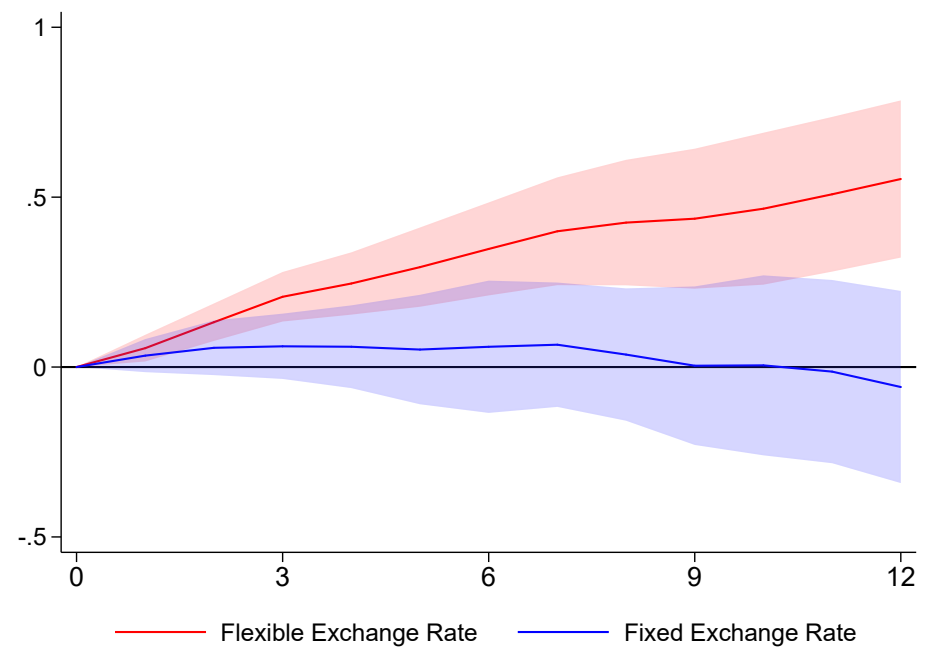

Source: Authors' calculations.

Note: The figure shows the cumulative response of consumer prices to a negative terms-of-trade shock of 1 percent. The response of flexible (fixed) exchange rate corresponds to $\hat{\beta}_{3}^{h}+\hat{\beta}_{4}^{h}+\hat{\beta}_{5}^{h} \times \overline{\text { anchor }}+\hat{\beta}_{6}^{h} \times \overline{\text { anchor }}\left(\hat{\beta}_{3}^{h}+\hat{\beta}_{5}^{h} \times \overline{\text { anchor }}\right)$ in equation (8), where $\overline{\text { anchor }}$ denotes the average of the anchoring index in the estimation sample. Shaded areas denote 95 percent confidence intervals computed with country-based cluster-robust standard errors.

Figure 8: Distribution of Anchoring Index among Floats

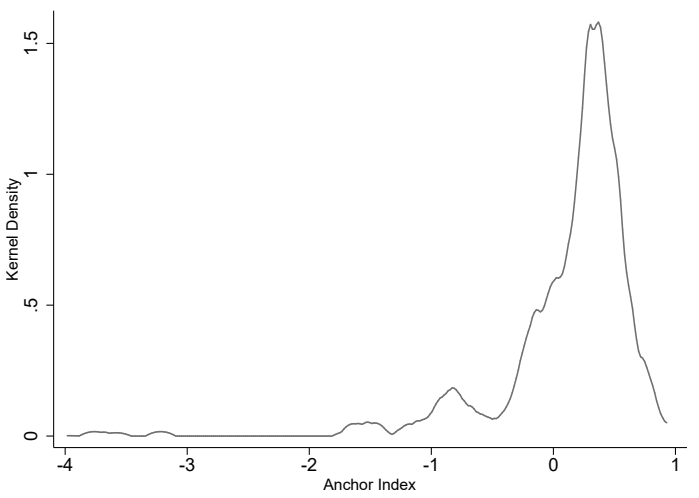

(a) $1998-2017$

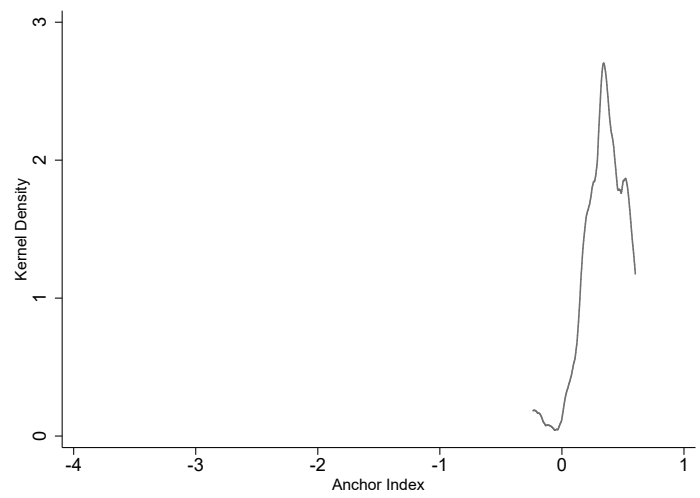

(b) $2012-2017$

Source: Authors' calculations.

Note: Floats corresponds to observations with coarse classifications of 3 and 4 in Ilzetzki et al. (2017). The standard deviations of anchoring in panel (a) is 0.68 and 0.27 in panel (b).

after 6 months for different degrees of anchoring. The solid grey line in panel (a) summarizes the marginal effect for floats of a negative shock to the commodity terms of trade at different values of the anchoring index. The dashed grey lines denote the 95 percent confidence interval. The black line shows the estimated kernel density of the anchoring index (i.e., distribution of anchoring) in the estimation sample. While the marginal effect at the $25^{\text {th }}$ percentile of anchoring is about 0.38 percent, it is much higher, about 0.93 percent, at the $10^{\text {th }}$ percentile of anchoring - that is, when the anchoring index is around -0.75 . At the other extreme of the distribution the marginal effect 
Figure 9: Response of Consumer Prices to a Terms-of-Trade Shock, by Anchoring

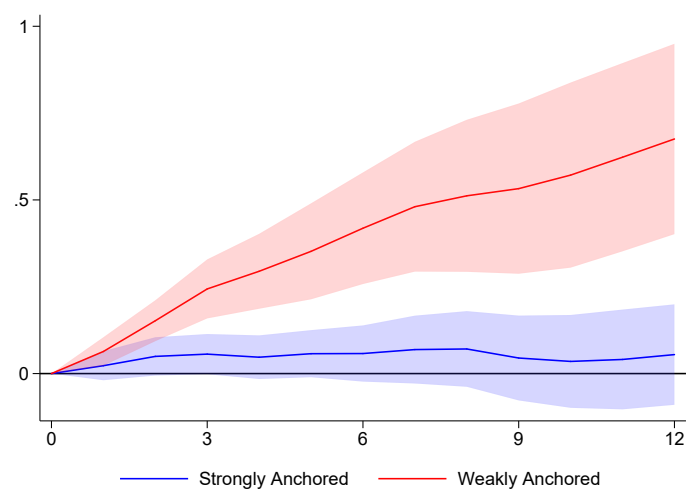

(a) Response by Anchoring Level

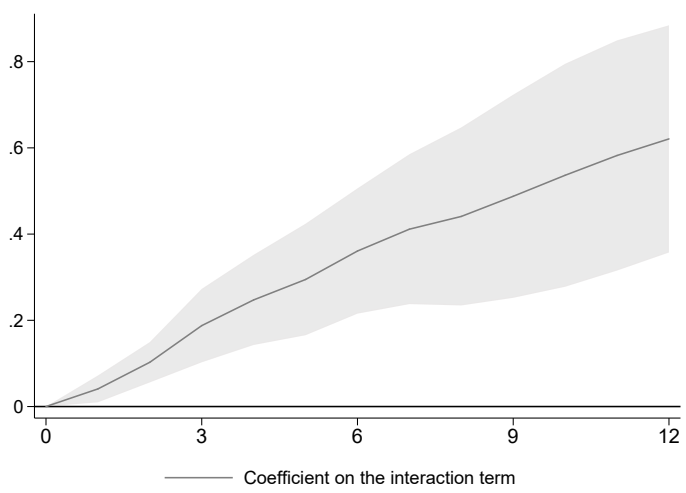

(b) Difference Between Responses

Source: Authors' calculations.

Note: The figures show the cumulative response of consumer prices to a negative terms-of-trade shock of 1 percent when the exchange rate regime is flexible. The response under strongly (weakly) anchored expectations in panel (a) corresponds to $\hat{\beta}_{3}^{h}+\hat{\beta}_{4}^{h}+\hat{\beta}_{5}^{h} \times$ anchor $_{p 75}+\hat{\beta}_{6}^{h} \times$ anchor $_{p 75}\left(\hat{\beta}_{3}^{h}+\hat{\beta}_{4}^{h}+\hat{\beta}_{5}^{h} \times\right.$ anchor $_{p 25}+\hat{\beta}_{6}^{h} \times$ anchor $\left._{p 25}\right)$ in equation (8), where anchor $_{p 75}$ (anchor $_{p 25}$ ) denotes the $75^{\text {th }}\left(25^{\text {th }}\right.$ ) percentile of the anchoring index in the estimation sample. Shaded areas denote 95 percent confidence intervals computed with country-based cluster-robust standard errors.

is negative (e.g., it is $[-0.17]$ percent at the $95^{\text {th }}$ percentile). This probably reflects that, for those economies, the effect on prices from weaker domestic demand as a result of the negative income effect predominates.

Figure 10: Marginal Effect on Consumer Prices after 6 Months, by Anchoring

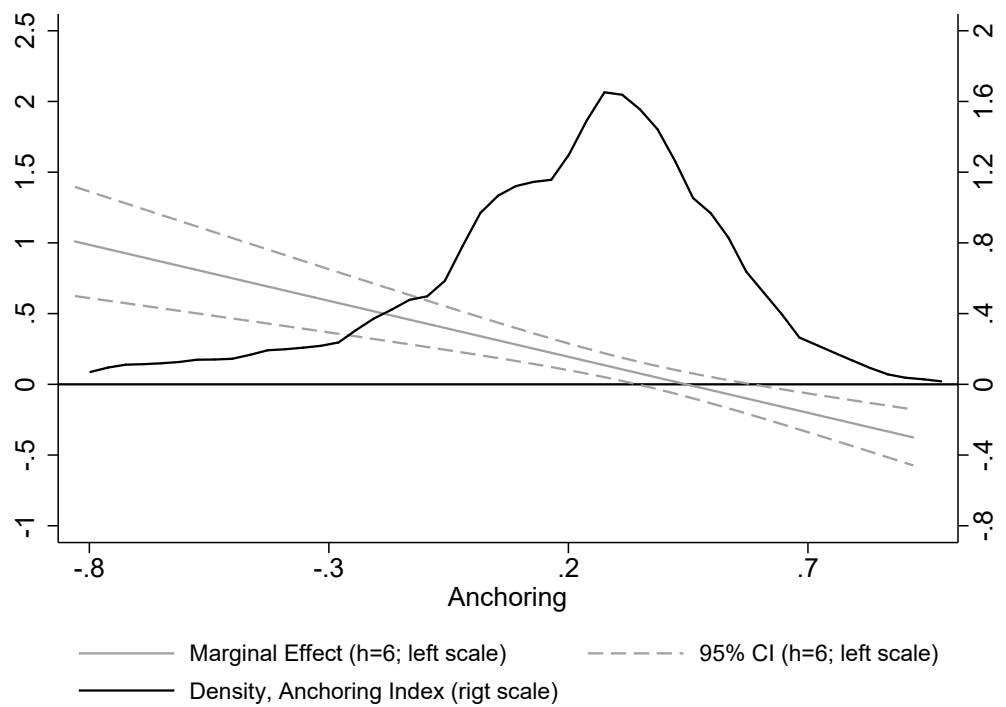

Source: Authors' calculations.

Note: The figure shows the marginal effect after six months of a negative terms-of-trade shock of 1 percent on consumer prices when the exchange rate regime is flexible. The chart reports results for levels of anchoring greater or equal than -0.83 . 
We then explore the implications of anchoring for the persistence of the inflation rate. To this end, we estimate equation (7) but redefining the dependent variable as the month-on-month inflation rate (that is, $\Delta p_{i, t+h-1}$ for $h=1, \ldots, 12$ ) annualized, rather than the cumulative change in the price level. The results are reported in Figure $11 .{ }^{19}$ The inflation rate increases by about 1.10 percentage points three months after the shock when inflation expectations are poorly anchored. Moreover, the reaction of inflation is very persistent: on average, the month-on-month inflation rate remains more than 0.60 percentage point above its pre-shock level even 12 months after the shock.

Inflation increases somewhat under anchored expectations - the response after two months is about 0.32 percentage points and statistically significant at the 95 percent confidence level. This is to be expected if the currency depreciation triggers an adjustment in relative prices and there is some downward rigidity in nominal prices. But when expectations are strongly anchored, the inflation rate returns quickly to its pre-shock level: the response of inflation is already not statistically different from zero three months after the shock.

Figure 11: Response of Inflation to a Terms-of-Trade Shock, by Anchoring

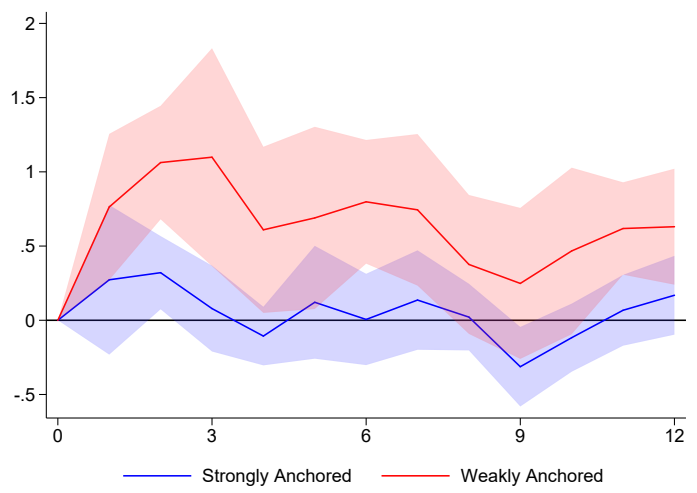

(a) Response by Anchoring Level

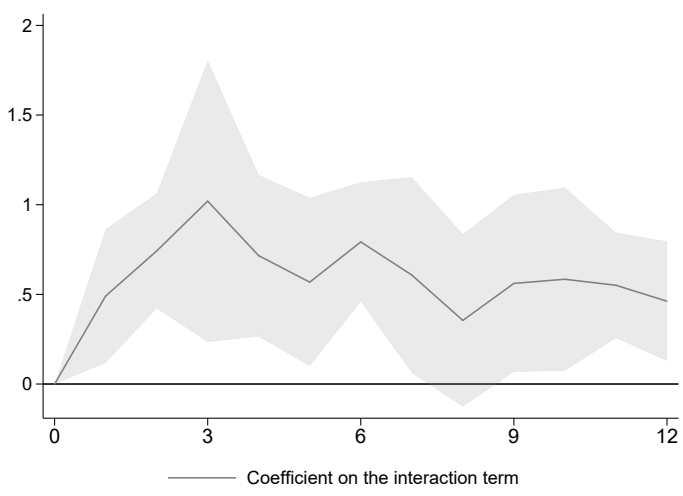

(b) Difference Between Responses

Source: Authors' calculations.

Note: The figures show the cumulative response of consumer price inflation to a negative terms-of-trade shock of 1 percent when the exchange rate regime is flexible. The response under strongly (weakly) anchored expectations in panel (a) corresponds to $\hat{\beta}_{3}^{h}+\hat{\beta}_{4}^{h}+\hat{\beta}_{5}^{h} \times$ anchor $_{p 75}+\hat{\beta}_{6}^{h} \times$ anchor $_{p 75}\left(\hat{\beta}_{3}^{h}+\hat{\beta}_{4}^{h}+\hat{\beta}_{5}^{h} \times\right.$ anchor $_{p 25}+\hat{\beta}_{6}^{h} \times$ anchor $\left._{p 25}\right)$ in equation (8), where anchor an (anchor ${ }_{p 25}$ ) denotes the $75^{\text {th }}\left(25^{\text {th }}\right.$ ) percentile of the anchoring index in the estimation sample. Shaded areas denote 95 percent confidence intervals computed with country-based cluster-robust standard errors.

\subsection{Exchange Rate Depreciation and Pass-Through}

These results suggest that the persistence of inflationary shocks is indeed larger when inflation expectation are poorly anchored. Given that the shock we are considering, a terms-of-trade shock, affects consumer prices primarily through the response of the exchange rate (as shown in Figure 7), a natural follow up question is whether the higher inflation persistence when expectations are poorly anchored is due to a larger currency depreciation, or to a larger exchange rate passthrough.

To answer this question, we explore whether the response of the exchange rate to a shock to the

\footnotetext{
${ }^{19}$ The estimation results for all horizons $h$ are shown in Annex Table A.3.
} 
Figure 12: Response of the Nominal Exchange Rate to a Terms-of-Trade Shock, by Anchoring

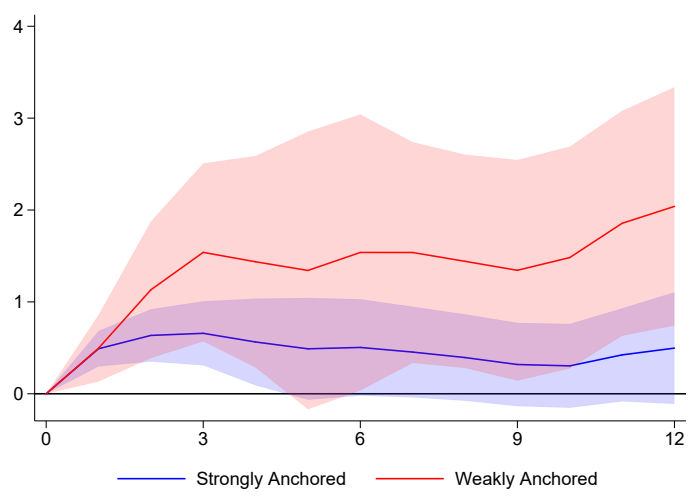

(a) Response by Anchoring Level

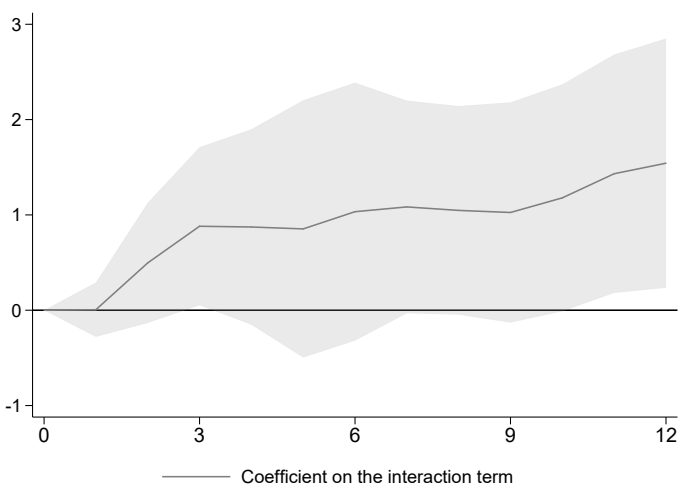

(b) Difference Between Responses

Source: Authors' calculations.

Note: The figures show the cumulative response of the nominal exchange rate to a negative terms-of-trade shock of 1 percent when the exchange rate regime is flexible. The response under strongly (weakly) anchored expectations in panel (a) corresponds to $\hat{\beta}_{3}^{h}+\hat{\beta}_{4}^{h}+\hat{\beta}_{5}^{h} \times$ anchor $_{p 75}+\hat{\beta}_{6}^{h} \times$ anchor $_{p 75}\left(\hat{\beta}_{3}^{h}+\hat{\beta}_{4}^{h}+\hat{\beta}_{5}^{h} \times\right.$ anchor $_{p 25}+\hat{\beta}_{6}^{h} \times$ anchor $\left._{p 25}\right)$ in equation (8), where anchor $p 75$ ( anchor $_{p 25}$ ) denotes the $75^{\text {th }}\left(25^{\text {th }}\right)$ percentile of the anchoring index in the estimation sample. Shaded areas denote 95 percent confidence intervals computed with country-based cluster-robust standard errors.

Figure 13: Response of the Nominal Effective Exchange Rate to a Terms-of-Trade Shock, by Anchoring

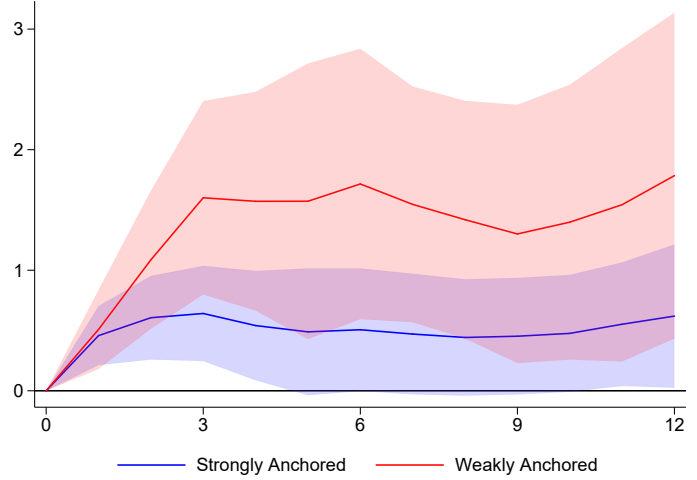

(a) Response by Anchoring Level

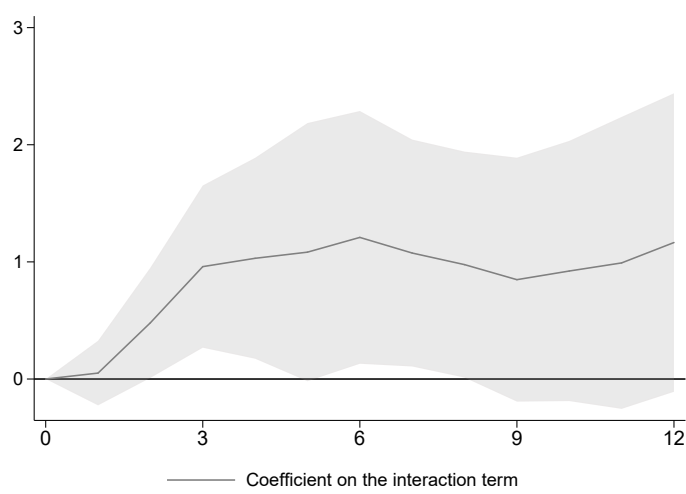

(b) Difference Between Responses

Source: Authors' calculations.

Note: The figures show the cumulative response of the nominal effective exchange rate to a negative terms-of-trade shock of 1 percent when the exchange rate regime is flexible. The response under strongly (weakly) anchored expectations in panel (a) corresponds to $\hat{\beta}_{3}^{h}+\hat{\beta}_{4}^{h}+\hat{\beta}_{5}^{h} \times$ anchor $_{p 75}+\hat{\beta}_{6}^{h} \times$ anchor $_{p 75}\left(\hat{\beta}_{3}^{h}+\hat{\beta}_{4}^{h}+\hat{\beta}_{5}^{h} \times\right.$ anchor $_{p 25}+$ $\hat{\beta}_{6}^{h} \times$ anchor $\left._{p 25}\right)$ in equation (8), where anchor $_{p 75}\left(\right.$ anchor $\left._{p 25}\right)$ denotes the $75^{\text {th }}\left(25^{\text {th }}\right)$ percentile of the anchoring index in the estimation sample. Shaded areas denote 95 percent confidence intervals computed with country-based cluster-robust standard errors.

terms of trade is significantly different for economies with strongly and weakly anchored inflation expectations. We estimate the model in equation (7) but substituting consumer prices $\left(p_{i, t}\right)$ with the natural logarithm of, alternatively, the nominal bilateral exchange rate (in local currency per U.S. dollar) and the import-weighted nominal effective exchange rate (as in Gopinath, 2015; and 
Figure 14: Marginal Effect on the Nominal Exchange Rate after 6 Months, by Anchoring

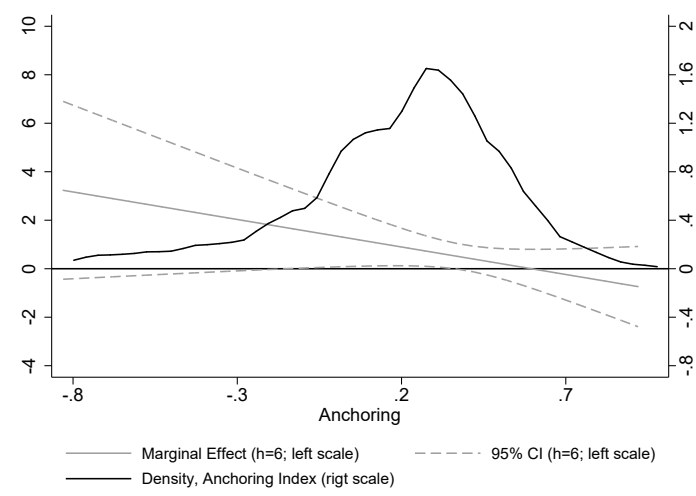

(a) On Nominal Exchange Rates

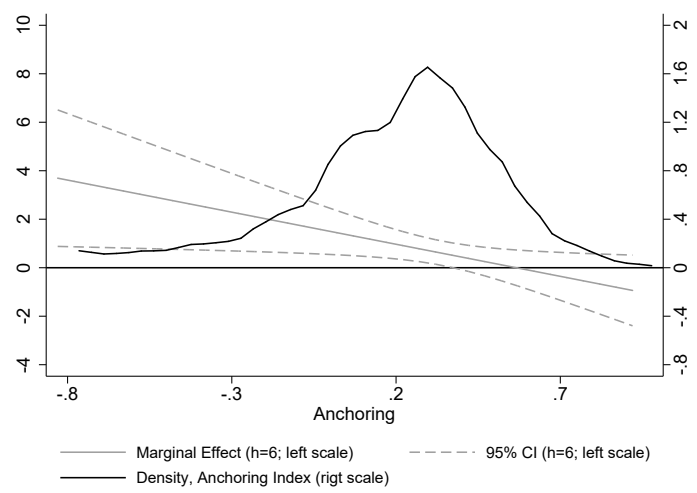

(b) On Nominal Effective Exchange Rates

Source: Authors' calculations.

Note: The figures show the marginal effect after six months of a negative terms-of-trade shock of 1 percent on the nominal exchange rate when the exchange rate regime is flexible. The charts report results for levels of anchoring greater or equal than -0.83 .

Carrière-Swallow et al., 2016). ${ }^{20}$ The latter is given by:

$$
\Delta n e e r_{i, t}=\sum_{j=1}^{J} \omega_{i j, t}\left(\Delta e_{i, t}-\Delta e_{j, t}\right), \text { with } i \neq j
$$

where $e_{i, t}$ is the natural logarithm of country $i$ 's bilateral exchange rate (expressed in local currency per U.S. dollar, so that an increase denotes a depreciation of the domestic currency); $\Delta$ is the first difference operator; and $\omega_{i j, t}$ is the share of exports from country $j$ to country $i$ in country $i$ 's total imports as reported in the IMF's Direction of Trade Statistics, lagged one year, and measured at annual frequency.

The results using the nominal exchange rate indicate that the magnitude of the depreciation following terms-of-trade shocks is not significantly related to the extent of anchoring. Figure 12 shows the cumulative response of the exchange rate up to 12 months for floats after a negative termsof-trade shock when inflation expectations are strongly anchored (anchor $=75^{\text {th }}$ percentile of the sample distribution) and weakly anchored (anchor $=25^{\text {th }}$ percentile). The response of the exchange rate is somewhat larger for weakly-anchored countries than for countries with well anchored expectations, although the difference is generally not statistically significant. Figure 14, panel (a), focuses on the cumulative response after 6 months and shows that the marginal effect of a negative shock to the commodity terms of trade does not differ significantly for different values of the anchoring index.

The results using the nominal effective exchange rate suggest that the depreciation may also be somewhat larger when expectations are poorly anchored (Figure 13 and Figure 14, panel [b]). But, again, the difference is only statistically significant for a few horizons.

\footnotetext{
${ }^{20} \mathrm{By}$ taking into account bilateral trade linkages, the nominal effective exchange rate may be able to summarize more closely the complete set of relative price adjustments that can be expected to affect consumer prices. However, if a substantial fraction of bilateral trade is invoiced in US dollars (as documented in Gopinath, 2015), the nominal exchange rate with respect to the US dollar may be a reasonable choice.
} 
The weak significance of the marginal effect of anchoring on the exchange rate response, together with the strong significance for consumer prices, suggest that two things are at play. When inflation expectations are poorly anchored, the exchange rate appears to depreciate by more in response to a given deterioration in the terms of trade. But, in addition, the pass-through rate from a given currency depreciation triggered by a terms-of-trade shock seems to be larger when inflation expectations are poorly anchored. ${ }^{21}$

\subsection{Robustness}

In this section we present a set of robustness tests to our main findings. In Figure 15 we show the estimated differences between the response of the CPI based on equation (7) when inflation expectations are strongly and weakly anchored. The baseline results are reported in panel (a) for convenience.

Panel (b) and (c) show the results under different exchange rate classifications. Panel (b) is still based on Ilzetzki et al. (2017), but we include observations of free falling exchange rates - that in most classifications are lumped together with ordinary flexible exchange rate regimes although they correspond to regimes with very high inflation (over 40 percent per year). Panel (c), instead, uses the updated version of the exchange rate classification of Shambaugh (2004). The results are very similar to those in the baseline exercise.

In panel (d) we report the results when the standard errors are corrected using the Driscoll and Kraay (1998) procedure - rather than clustering by country - which has the advantage that it takes cross-sectional dependence into account. The confidence intervals are wider under this alternative. But we can still reject the null that the responses of consumer prices under strongly and weakly anchored expectations are equal with a 95 percent confidence level.

One potential concern is that although the anchoring index is predetermined at the time of the shock (i.e., it is computed over the preceding six years), Metric \#4-which captures the sensitivity of long-term expectations to inflation surprises - could be higher (i.e., reflect poor anchoring) if inflation is inherently more persistent. However, the robustness exercise reported in panel (e) shows that our main result holds when we exclude Metric \#4 from the anchoring index.

Finally, our baseline analysis uses the anchoring index based on three-year ahead inflation expectations. The results in panel (f) shows that our main result holds when we use, instead, five-year ahead inflation expectations.

\section{Conclusions}

Theory indicates that that any temporary inflationary shock has a less persistent effect on consumer price dynamics when expectations are anchored. The contribution of this paper is twofold: (i) it constructs a novel index measuring the extent of anchoring of long-term inflation expectations for a large sample of 45 advanced and emerging economies since 1989; and (ii) it provides an empirical assessment of the influence of inflation expectations' anchoring on inflation persistence.

\footnotetext{
${ }^{21}$ This result is consistent with Carrière-Swallow et al. (2016), who find that exchange rate pass-through rates are negatively related to the dispersion of inflation forecasts across individual forecasters, a proxy for the extent of anchoring of inflation expectations.
} 
We first use survey-based long-term inflation forecasts to construct an index of inflation expectations' anchoring for 45 advanced and emerging economies starting in 1989. We document that the extent of anchoring of inflation expectations improved significantly over the past two decades, especially among emerging economies. But substantial cross-country heterogeneity persists, which appears related to inflation performance and macroeconomic factors including the quality of monetary and fiscal frameworks.

We then estimate the response of consumer prices to external shocks to the terms of trade - captured by changes in country-specific terms of trade indices based on international commodity pricesconditional on the exchange rate regime and the extent of anchoring of inflation expectations. We find that when inflation expectations are poorly anchored - that is, when the anchoring index is set at the $25^{\text {th }}$ percentile of the sample distribution - a negative terms-of-trade shock among countries with flexible exchange rates leads to a significant and persistent increase in consumer price inflation. The annualized month-on-month inflation rate remains more than 0.6 percentage point above its pre-shock level one year after a deterioration in the commodity terms of trade index equivalent to a drop of aggregate disposable income of one percent of GDP. When inflation expectations are strongly anchored - the anchoring index is set at the $75^{\text {th }}$ percentile of the sample distribution - the response of inflation is much smaller - about 0.3 percent after two months - and returns to its pre-shock level only three months after the shock.

Our findings have important implications for monetary policy and underscore the importance of shoring up the credibility of the nominal anchor. When the public's expectations about the future path of inflation are poorly anchored, temporary shocks to inflation have a more durable effect on the dynamics of consumer prices and require a stronger policy reaction to bring inflation under control. 
Figure 15: Robustness Exercises-Response of Consumer Prices

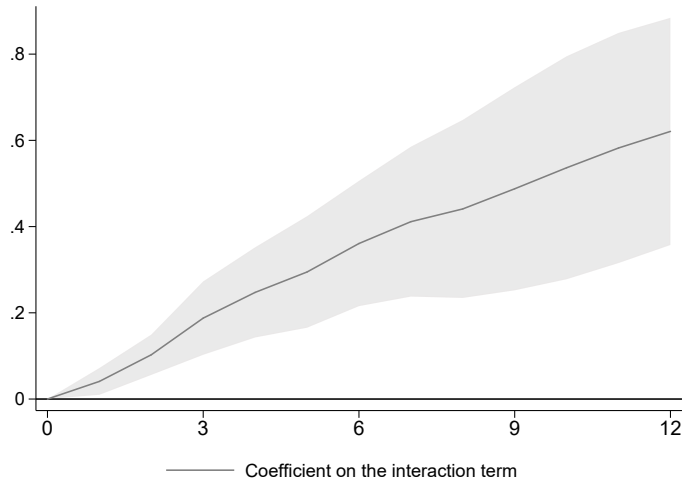

(a) Baseline

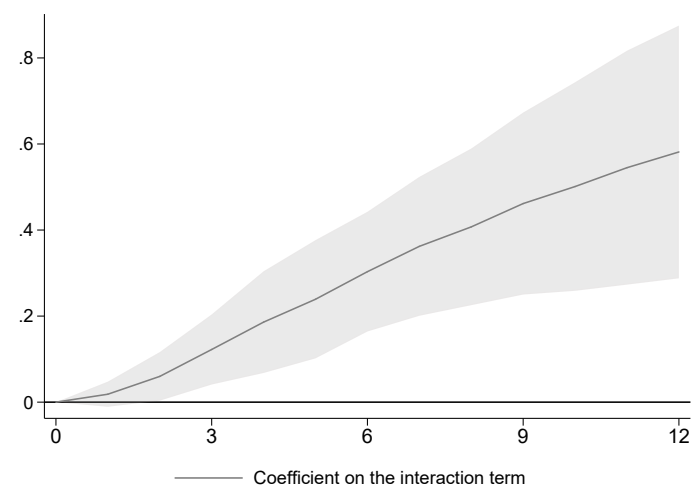

(c) Shambaugh (2004) exchange rate classification

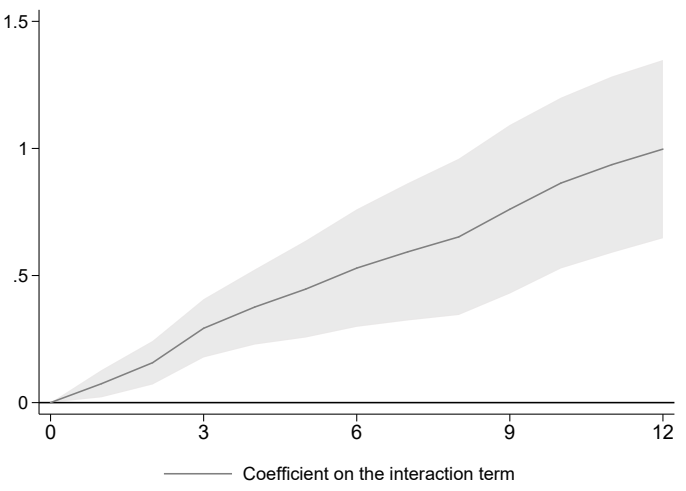

(e) Excluding Metric \#4

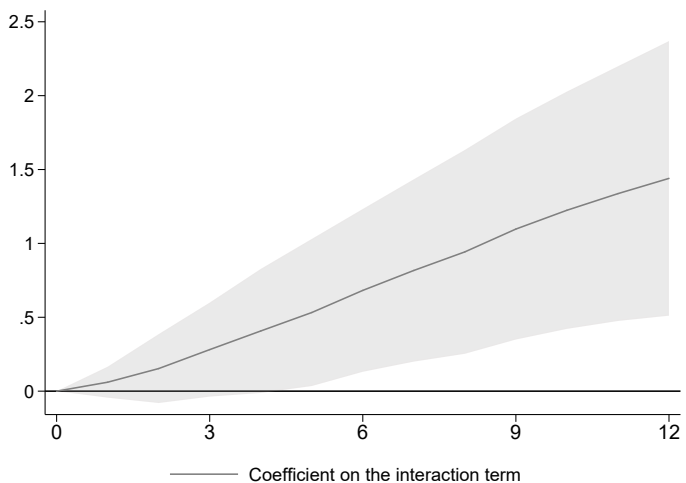

(b) Including free falling exchange rates

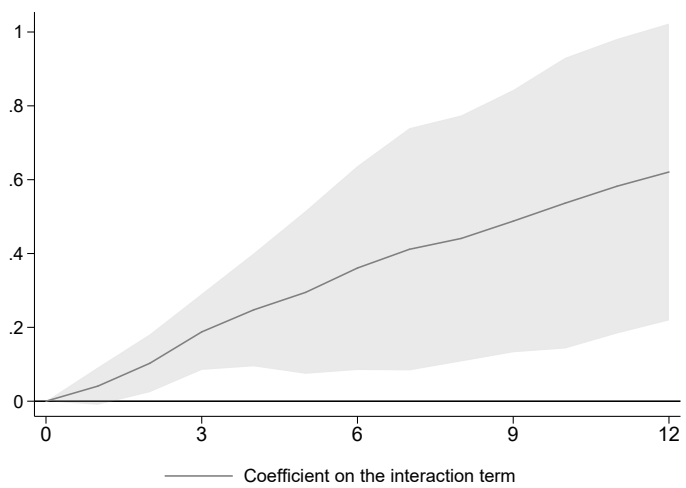

(d) Driscoll and Kraay (1998) standard errors

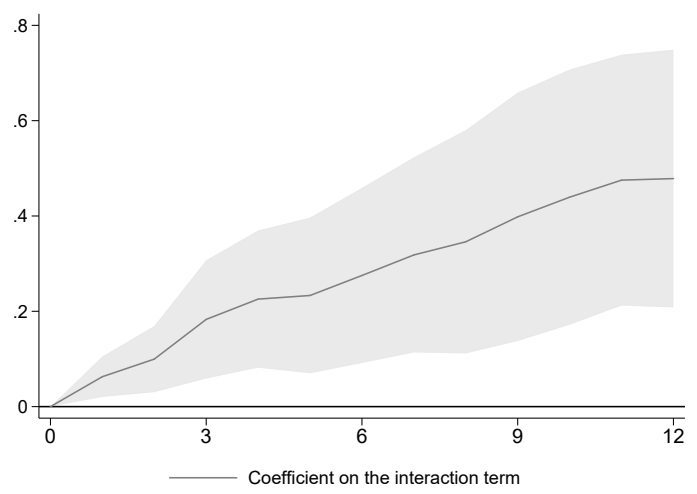

(f) Using five-years-ahead inflation expectations

Source: Authors' calculations.

Note: The figures show the difference in the cumulative response of consumer prices to a negative terms-of-trade shock of 1 percent when the exchange rate regime is flexible under strongly and weakly anchored expectations (which correspond to the $75^{\text {th }}$ and the $25^{\text {th }}$ percentile, respectively, of the anchoring index in the estimation sample). Shaded areas denote 95 percent confidence intervals computed with country-based cluster-robust standard errors. 


\section{References}

Aghion, Philippe, George-Marios Angeletos, Abhijit Banerjee, and Kalina Manova (2010). "Volatility and growth: Credit constraints and the composition of investment". In: Journal of Monetary Economics 57.3, pp. 246-265.

Aizenman, Joshua, Sebastian Edwards, and Daniel Riera-Crichton (2012). "Adjustment patterns to commodity terms of trade shocks: the role of exchange rate and international reserves policies". In: Journal of International Money and Finance 31.8, pp. 1990-2016.

Alichi, Ali, Huigang Chen, Kevin Clinton, Charles Freedman, Marianne Johnson, Ondra Kamenik, Turgut Kisinbay, and Douglas Laxton (2009). "Inflation targeting under imperfect policy credibility". In: International Monetary Fund Working Paper 09/94.

Alogoskoufis, George S and Ron Smith (1991). "The Phillips curve, the persistence of inflation, and the Lucas critique: Evidence from exchange-rate regimes". In: The American Economic Review, pp. 1254-1275.

Argov, Eyal, David Rose, Philippe Karam, Natan Epstein, and Douglas Laxton (2007). "Endogenous monetary policy credibility in a small macro model of Israel". In: International Monetary Fund Working Paper 07/207.

Auerbach, Alan J and Yuriy Gorodnichenko (2012). "Fiscal multipliers in recession and expansion". In: Fiscal policy after the financial crisis. University of Chicago press, pp. 63-98.

Benati, Luca (2008). "Investigating inflation persistence across monetary regimes". In: The Quarterly Journal of Economics 123.3, pp. 1005-1060.

Bernanke, Ben (2007). "Inflation expectations and inflation forecasting". In: Board of Governors of the Federal Reserve System (US).

Brito, Steve, Yan Carriere-Swallow, and Bertrand Gruss (2018). "Disagreement about Future Inflation: Understanding the Benefits of Inflation Targeting and Transparency". In: International Monetary Fund Working Paper 18/24.

Capistrán, Carlos and Manuel Ramos-Francia (2010). "Does inflation targeting affect the dispersion of inflation expectations?" In: Journal of Money, Credit and Banking 42.1, pp. 113-134.

Carrière-Swallow, Yan, Bertrand Gruss, Nicolas Magud, and Fabian Valencia (2016). "Monetary Policy Credibility and Exchange Rate Pass-Through". In: International Monetary Fund Working Paper 16/240.

Celasun, Oya, R Gaston Gelos, and Alessandro Prati (2004). "Obstacles to disinflation: what is the role of fiscal expectations?" In: Economic Policy 19.40, pp. 442-481.

Chen, Yu-chin and Kenneth Rogoff (2003). "Commodity currencies". In: Journal of international Economics 60.1, pp. 133-160.

Cogley, Timothy, Giorgio E Primiceri, and Thomas J Sargent (2010). "Inflation-gap persistence in the US". In: American Economic Journal: Macroeconomics 2.1, pp. 43-69.

Cogley, Timothy and Thomas J Sargent (2005). "Drifts and volatilities: monetary policies and outcomes in the post WWII US". In: Review of Economic dynamics 8.2, pp. 262-302.

Cogley, Timothy and Argia M Sbordone (2008). "Trend inflation, indexation, and inflation persistence in the New Keynesian Phillips curve". In: American Economic Review 98.5, pp. 210126.

Combes, Jean-Louis, Xavier Debrun, Alexandru Minea, and René Tapsoba (2017). "Inflation Targeting, Fiscal Rules and the Policy Mix: Cross-effects and Interactions". In: The Economic Journal.

Cukierman, Alex and Allan H Meltzer (1986). "A theory of ambiguity, credibility, and inflation under discretion and asymmetric information". In: Econometrica: journal of the econometric society, pp. 1099-1128.

Demertzis, Maria, Massimiliano Marcellino, and Nicola Viegi (2012). "A credibility proxy: Tracking US monetary developments". In: The BE Journal of Macroeconomics 12.1. 
Dincer, N Nergiz and Barry Eichengreen (2014). "Central Bank Transparency and Independence: Updates and New Measures". In: International Journal of Central Banking 10.1, pp. 189-259.

Dovern, Jonas, Ulrich Fritsche, and Jiri Slacalek (2012). "Disagreement among forecasters in G7 countries". In: Review of Economics and Statistics 94.4, pp. 1081-1096.

Driscoll, John C and Aart C Kraay (1998). "Consistent Covariance Matrix Estimation with Spatially Dependent Panel Data". In: Review of Economics and Statistics 80.4, pp. 549-560.

Ehrmann, Michael (2015). "Targeting Inflation from Below: How Do Inflation Expectations Behave?" In: International Journal of Central Banking 11.4, pp. 213-249.

Fernández, Andrés, Stephanie Schmitt-Grohé, and Martín Uribe (2017). "World shocks, world prices, and business cycles: An empirical investigation". In: Journal of International Economics 108, S2-S14.

Fuhrer, Jeffrey C (2010). "Inflation persistence". In: Handbook of monetary economics. Vol. 3. Elsevier, pp. $423-486$.

Galí, Jordi and Mark Gertler (1999). "Inflation dynamics: A structural econometric analysis". In: Journal of monetary Economics 44.2, pp. 195-222.

Gopinath, Gita (2015). "The international price system". In: National Bureau of Economic Research Working Paper No. 21646.

Gruss, Bertrand (2014). "After the boom-commodity prices and economic growth in Latin America and the Caribbean". In: International Monetary Fund Working Paper 14/154.

Gürkaynak, Refet S, Andrew Levin, and Eric Swanson (2010). "Does Inflation Targeting Anchor Long-Run Inflation Expectations? Evidence from the U.S., UK, and Sweden". In: Journal of the European Economic Association 8.6, pp. 1208-1242.

Ilzetzki, Ethan, Carmen M Reinhart, and Kenneth S Rogoff (2017). "Exchange arrangements entering the 21st century: Which anchor will hold?" In: National Bureau of Economic Research Working Paper No. 23134.

Jordà, Òscar (2005). "Estimation and Inference of Impulse Responses by Local Projections". In: The American Economic Review 95.1, pp. 161-182.

Jordà, Òscar, Moritz Schularick, and Alan M Taylor (2015). "Betting the house". In: Journal of International Economics 96, S2-S18.

King, Mervyn (1995). "Credibility and Monetary Policy: Theory and Evidence". In: Scottish Journal of Political Economy 42.1, pp. 1-19.

Kose, M. Ayhan, Hideaki Matsuoka, Ugo Panizza, and Dana Vorisek (2018). "Inflation Expectations: Review and Evidence". In: Inflation in Emerging and Developing Economies. World Bank.

Kumar, Saten, Hassan Afrouzi, Olivier Coibion, and Yuriy Gorodnichenko (2015). "Inflation Targeting Does Not Anchor Inflation Expectations: Evidence from Firms in New Zealand". In: Brookings Papers on Economic Activity 46.2 (Fall), pp. 151-225.

Levin, Andrew T, Fabio M Natalucci, Jeremy M Piger, et al. (2004). "The macroeconomic effects of inflation targeting". In: Review-Federal Reserve Bank of Saint Louis 86.4, pp. 51-8.

Levin, Andrew and Jeremy Piger (2004). "Is inflation persistence intrinsic in industrial economies?" In: European Central Bank Working Paper No. 334.

Mishkin, Frederic S (2000). "Inflation targeting in emerging-market countries". In: American Economic Review 90.2, pp. 105-109.

- (2007). "Inflation dynamics". In: International Finance 10.3, pp. 317-334.

Mishkin, Frederic S and Miguel A Savastano (2001). "Monetary policy strategies for Latin America". In: Journal of Development Economics 66.2, pp. 415-444.

Montes, Gabriel Caldas, Tatiana Acar, et al. (2018). "Fiscal credibility and disagreement in expectations about inflation: evidence for Brazil". In: Economics Bulletin 38.2, pp. 826-843.

Pivetta, Frederic and Ricardo Reis (2007). "The persistence of inflation in the United States". In: Journal of Economic dynamics and control 31.4, pp. 1326-1358. 
Ricci, Luca Antonio, Gian Maria Milesi-Ferretti, and Jaewoo Lee (2013). "Real exchange rates and fundamentals: a cross-country perspective". In: Journal of Money, Credit and Banking 45.5 , pp. 845-865.

Savastano, Miguel A, Paul R Masson, and Sunil Sharma (1997). "The scope for inflation targeting in developing countries". In: International Monetary Fund Working Paper 97/130.

Shambaugh, Jay C (2004). "The effect of fixed exchange rates on monetary policy". In: The Quarterly Journal of Economics 119.1, pp. 301-352.

Williams, John C (2006). "The Phillips Curve in an Era of Well-Anchored Inflation Expectations". In: Federal Reserve Bank of San Francisco.

Woodford, Michael (2005). "Central Bank Communication and Policy Effectiveness". In: National Bureau of Economic Research Working Paper No. 11898. 


\section{Appendix A. Data Sample and Additional Results}

Figure A.1: Mean and Standard Deviation of Long-Term Inflation Forecasts-Data Availability

(Number of Countries)

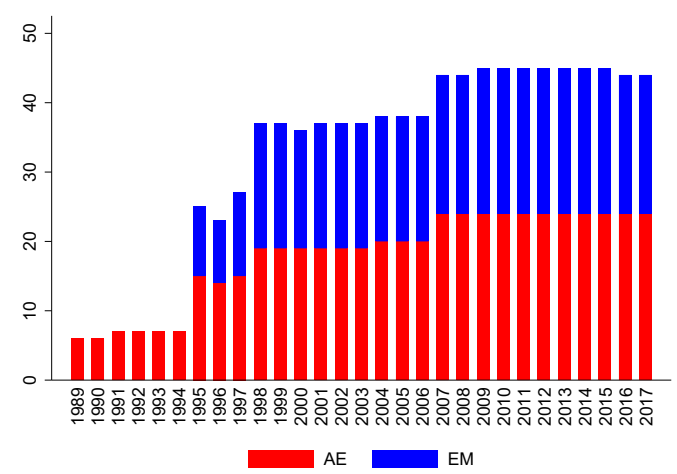

(a) Mean forecast

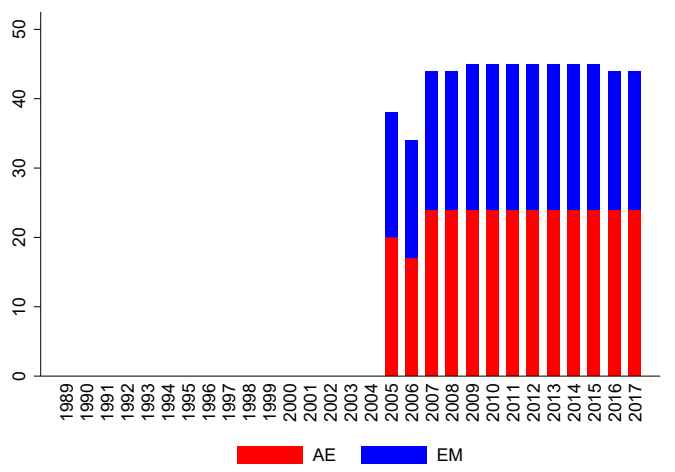

(b) Standard deviation of forecasts

Source: Consensus Economics.

Note: $\mathrm{AE}=$ advanced economies. $\mathrm{EM}=$ emerging economies.

Table A.1: Mean and Standard Deviation of Long-Term Inflation Forecasts-Data Availability

\begin{tabular}{|c|c|c|c|c|c|}
\hline \multicolumn{3}{|c|}{ Advanced Economies } & \multicolumn{3}{|c|}{ Emerging Economies } \\
\hline Country & $\begin{array}{c}\text { Mean } \\
\text { forecast }\end{array}$ & $\begin{array}{c}\text { Standard } \\
\text { deviation } \\
\text { of forecasts }\end{array}$ & Country & $\begin{array}{c}\text { Mean } \\
\text { forecast }\end{array}$ & $\begin{array}{c}\text { Standard } \\
\text { deviation } \\
\text { of forecasts }\end{array}$ \\
\hline AUS & 1991 & 2005 & ARG & 1993 & 2005 \\
\hline $\mathrm{CAN}$ & 1989 & 2005 & BGR & 2007 & 2007 \\
\hline $\mathrm{CHE}$ & 1998 & 2005 & BRA & 1995 & 2005 \\
\hline $\mathrm{CZE}$ & 1998 & 2005 & $\mathrm{CHL}$ & 1993 & 2005 \\
\hline DEU & 1989 & 2005 & $\mathrm{CHN}$ & 1995 & 2005 \\
\hline ESP & 1995 & 2005 & $\mathrm{COL}$ & 1997 & 2005 \\
\hline EST & 2007 & 2007 & HRV & 2007 & 2007 \\
\hline FRA & 1989 & 2005 & HUN & 1998 & 2005 \\
\hline GBR & 2004 & 2005 & IDN & 1995 & 2005 \\
\hline HKG & 1995 & 2005 & IND & 1995 & 2005 \\
\hline ITA & 1989 & 2005 & MEX & 1993 & 2005 \\
\hline JPN & 1989 & 2005 & MYS & 1995 & 2005 \\
\hline $\mathrm{KOR}$ & 1995 & 2005 & PER & 1997 & 2005 \\
\hline LTU & 2007 & 2007 & PHL & 2009 & 2009 \\
\hline LVA & 2007 & 2007 & POL & 1998 & 2005 \\
\hline NLD & 1995 & 2005 & $\mathrm{ROU}$ & 1998 & 2005 \\
\hline NOR & 1998 & 2005 & RUS & 1998 & 2005 \\
\hline NZL & 1995 & 2005 & THA & 1995 & 2005 \\
\hline SGP & 1995 & 2005 & TUR & 1998 & 2005 \\
\hline SVK & 1998 & 2005 & UKR & 1998 & 2005 \\
\hline SVN & 2007 & 2007 & VEN & 1993 & 2005 \\
\hline SWE & 1995 & 2005 & & & \\
\hline TWN & 1995 & 2005 & & & \\
\hline USA & 1989 & 2005 & & & \\
\hline
\end{tabular}


Figure A.2: Evolution of Anchoring Metrics, 1998-2017

(Three-Year-Ahead Inflation Expectations)

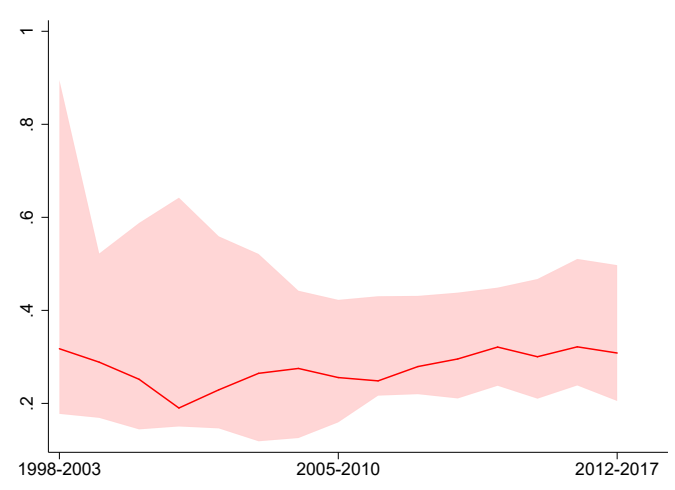

(a) AE, deviation of long-term inflation forecasts from target

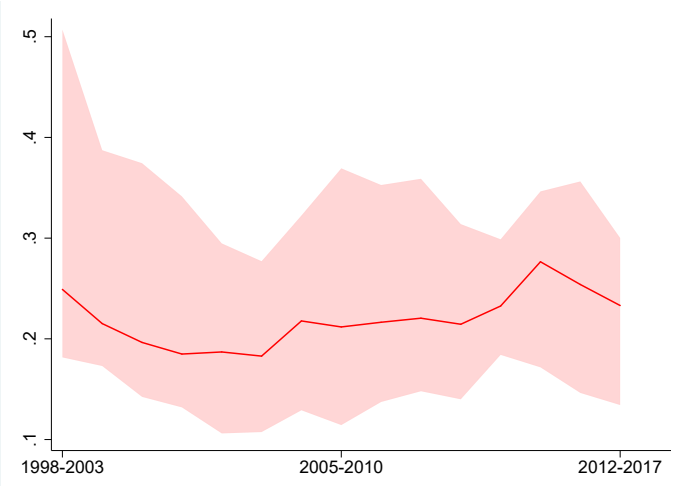

(c) AE, variability of mean long-term inflation forecasts

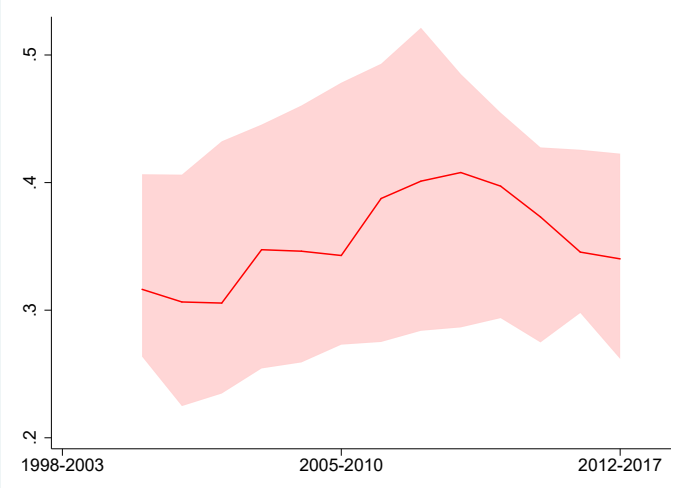

(e) AE, dispersion of long-term inflation forecasts

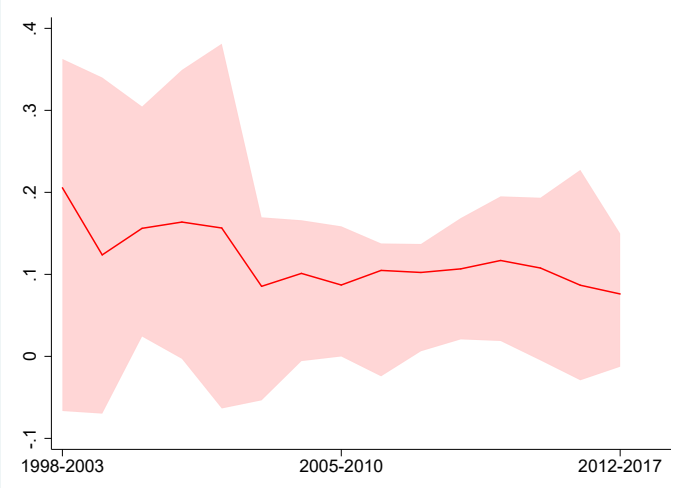

(g) AE, sensitivity of long-term inflation forecasts to inflation surprises

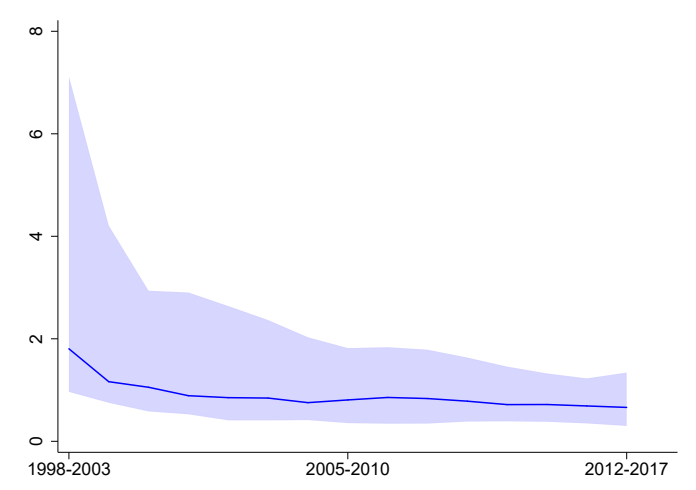

(b) EM, deviation of long-term inflation forecasts from target

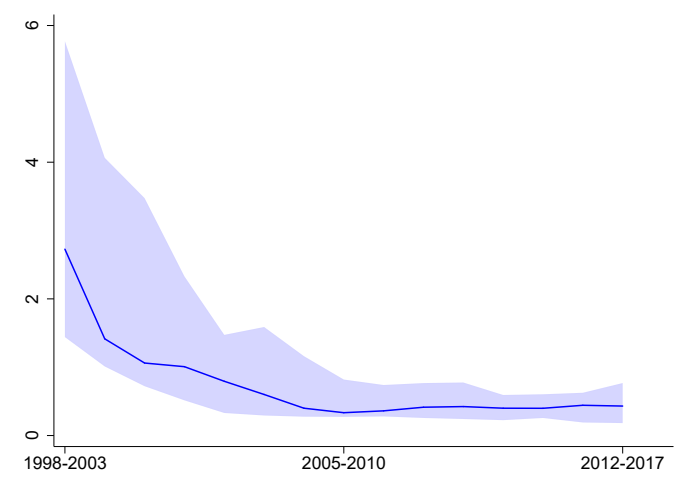

(d) EM, variability of mean long-term inflation forecasts

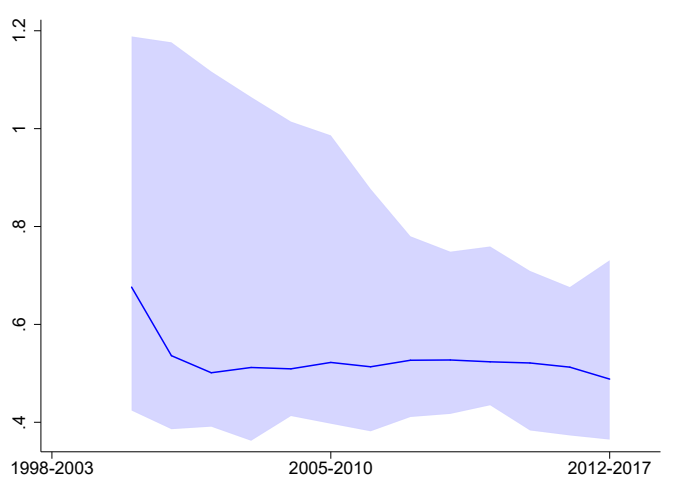

(f) EM, dispersion of long-term inflation forecasts

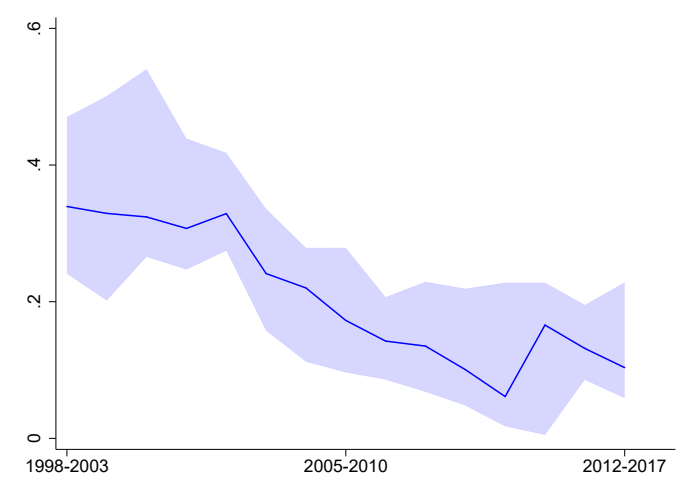

(h) EM, sensitivity of long-term inflation forecasts to inflation surprises

Source: Authors' calculations.

Note: The figures show the evolution of anchoring metrics computed over six-year rolling windows. The lines denote the medians across countries. The shaded areas denote interquartile ranges. A lower value denotes better-

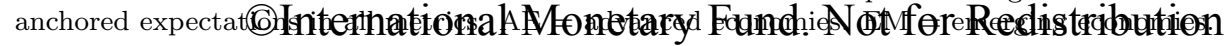


Table A.2: Cumulative Response of Consumer Prices-Estimation Results

\begin{tabular}{|c|c|c|c|c|c|c|c|c|c|c|c|c|}
\hline & $\begin{array}{c}(1) \\
h=1\end{array}$ & $\begin{array}{c}(2) \\
h=2\end{array}$ & $\begin{array}{c}(3) \\
h=3\end{array}$ & $\begin{array}{c}(4) \\
h=4\end{array}$ & $\begin{array}{c}(5) \\
h=5\end{array}$ & $\begin{array}{c}(6) \\
h=6\end{array}$ & $\begin{array}{c}(7) \\
h=7\end{array}$ & $\begin{array}{c}(8) \\
h=8\end{array}$ & $\begin{array}{c}(9) \\
h=9\end{array}$ & $\begin{array}{c}(10) \\
h=10\end{array}$ & $\begin{array}{c}(11) \\
h=11\end{array}$ & $\begin{array}{c}(12) \\
h=12\end{array}$ \\
\hline$\Delta c t o t$ & $\begin{array}{c}0.033 \\
(0.025)\end{array}$ & $\begin{array}{c}0.056 \\
(0.041)\end{array}$ & $\begin{array}{c}0.061 \\
(0.049)\end{array}$ & $\begin{array}{c}0.060 \\
(0.062)\end{array}$ & $\begin{array}{c}0.051 \\
(0.082)\end{array}$ & $\begin{array}{c}0.060 \\
(0.099)\end{array}$ & $\begin{array}{c}0.065 \\
(0.093)\end{array}$ & $\begin{array}{c}0.036 \\
(0.099)\end{array}$ & $\begin{array}{c}0.003 \\
(0.119)\end{array}$ & $\begin{array}{c}0.004 \\
(0.135)\end{array}$ & $\begin{array}{l}-0.015 \\
(0.137)\end{array}$ & $\begin{array}{c}-0.061 \\
(0.144)\end{array}$ \\
\hline flex & $\begin{array}{c}0.024 \\
(0.017)\end{array}$ & $\begin{array}{c}0.049 \\
(0.037)\end{array}$ & $\begin{array}{c}0.078 \\
(0.057)\end{array}$ & $\begin{array}{c}0.109 \\
(0.075)\end{array}$ & $\begin{array}{c}0.145 \\
(0.092)\end{array}$ & $\begin{array}{c}0.178 \\
(0.110)\end{array}$ & $\begin{array}{c}0.209 \\
(0.129)\end{array}$ & $\begin{array}{c}0.245 \\
(0.150)\end{array}$ & $\begin{array}{c}0.280 \\
(0.174)\end{array}$ & $\begin{array}{c}0.306 \\
(0.197)\end{array}$ & $\begin{array}{c}0.330 \\
(0.221)\end{array}$ & $\begin{array}{c}0.362 \\
(0.245)\end{array}$ \\
\hline anchor & $\begin{array}{c}-0.074^{* *} \\
(0.032)\end{array}$ & $\begin{array}{c}-0.170^{* *} \\
(0.075)\end{array}$ & $\begin{array}{c}-0.265^{* *} \\
(0.114)\end{array}$ & $\begin{array}{c}-0.347^{* *} \\
(0.149)\end{array}$ & $\begin{array}{c}-0.418^{* *} \\
(0.181)\end{array}$ & $\begin{array}{c}-0.464^{* *} \\
(0.207)\end{array}$ & $\begin{array}{c}-0.503^{* *} \\
(0.232)\end{array}$ & $\begin{array}{c}-0.542^{* *} \\
(0.258)\end{array}$ & $\begin{array}{c}-0.579^{* *} \\
(0.280)\end{array}$ & $\begin{array}{c}-0.594^{*} \\
(0.299)\end{array}$ & $\begin{array}{c}-0.601^{*} \\
(0.320)\end{array}$ & $\begin{array}{c}-0.617^{*} \\
(0.340)\end{array}$ \\
\hline anchor $\mathrm{X}$ flex & $\begin{array}{c}0.024 \\
(0.027)\end{array}$ & $\begin{array}{c}0.077 \\
(0.064)\end{array}$ & $\begin{array}{c}0.120 \\
(0.096)\end{array}$ & $\begin{array}{c}0.131 \\
(0.120)\end{array}$ & $\begin{array}{c}0.125 \\
(0.141)\end{array}$ & $\begin{array}{c}0.078 \\
(0.160)\end{array}$ & $\begin{array}{c}0.018 \\
(0.181)\end{array}$ & $\begin{array}{l}-0.056 \\
(0.205)\end{array}$ & $\begin{array}{l}-0.140 \\
(0.232)\end{array}$ & $\begin{array}{l}-0.241 \\
(0.261)\end{array}$ & $\begin{array}{l}-0.353 \\
(0.300)\end{array}$ & $\begin{array}{l}-0.449 \\
(0.339)\end{array}$ \\
\hline$\Delta$ ctot $\mathrm{X}$ anchor & $\begin{array}{c}0.071^{* *} \\
(0.031)\end{array}$ & $\begin{array}{c}0.085 \\
(0.051)\end{array}$ & $\begin{array}{c}0.063 \\
(0.073)\end{array}$ & $\begin{array}{c}0.016 \\
(0.086)\end{array}$ & $\begin{array}{c}0.002 \\
(0.075)\end{array}$ & $\begin{array}{c}0.019 \\
(0.078)\end{array}$ & $\begin{array}{c}0.046 \\
(0.103)\end{array}$ & $\begin{array}{c}0.048 \\
(0.105)\end{array}$ & $\begin{array}{c}0.083 \\
(0.115)\end{array}$ & $\begin{array}{c}0.207 \\
(0.134)\end{array}$ & $\begin{array}{c}0.257 \\
(0.157)\end{array}$ & $\begin{array}{c}0.275 \\
(0.172)\end{array}$ \\
\hline$\Delta$ ctot $\mathrm{X}$ anchor $\mathrm{X}$ flex & $\begin{array}{c}-0.160^{* * *} \\
(0.049)\end{array}$ & $\begin{array}{c}-0.310^{* * *} \\
(0.076)\end{array}$ & $\begin{array}{c}-0.475 * * * \\
(0.109)\end{array}$ & $\begin{array}{c}-0.559^{* * *} \\
(0.115)\end{array}$ & $\begin{array}{c}-0.649^{* * *} \\
(0.132)\end{array}$ & $\begin{array}{c}-0.810^{* * *} \\
(0.168)\end{array}$ & $\begin{array}{c}-0.949^{* * *} \\
(0.178)\end{array}$ & $\begin{array}{c}-1.016^{* * *} \\
(0.219)\end{array}$ & $\begin{array}{c}-1.154^{* * *} \\
(0.251)\end{array}$ & $\begin{array}{c}-1.385^{* * *} \\
(0.257)\end{array}$ & $\begin{array}{c}-1.535^{* * *} \\
(0.250)\end{array}$ & $\begin{array}{c}-1.638^{* * *} \\
(0.247)\end{array}$ \\
\hline
\end{tabular}

Source: Authors' calculations.

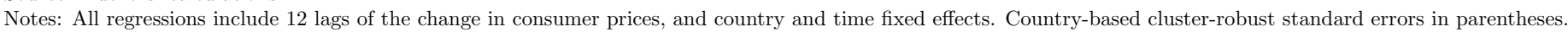

$\Delta$ ctot is reversed so that a positive change denotes a deterioration in the terms of trade. ${ }^{* * *} p<0.01,{ }^{* *} p<0.05, * p<0.1$.

Table A.3: Response of Consumer Price Inflation-Estimation Results

\begin{tabular}{|c|c|c|c|c|c|c|c|c|c|c|c|c|}
\hline & $\begin{array}{c}(1) \\
h=1\end{array}$ & $\begin{array}{c}(2) \\
h=2\end{array}$ & $\begin{array}{c}(3) \\
h=3\end{array}$ & $\begin{array}{c}(4) \\
h=4\end{array}$ & $\begin{array}{c}(5) \\
h=5\end{array}$ & $\begin{array}{c}(6) \\
h=6\end{array}$ & $\begin{array}{c}(7) \\
h=7\end{array}$ & $\begin{array}{c}(8) \\
h=8\end{array}$ & $\begin{array}{c}(9) \\
h=9\end{array}$ & $\begin{array}{c}(10) \\
h=10\end{array}$ & $\begin{array}{c}(11) \\
h=11\end{array}$ & $\begin{array}{c}(12) \\
h=12\end{array}$ \\
\hline$\Delta c t o t$ & $\begin{array}{c}0.397 \\
(0.297)\end{array}$ & $\begin{array}{c}0.276 \\
(0.279)\end{array}$ & $\begin{array}{c}0.054 \\
(0.273)\end{array}$ & $\begin{array}{c}-0.012 \\
(0.288)\end{array}$ & $\begin{array}{c}-0.098 \\
(0.355)\end{array}$ & $\begin{array}{c}0.096 \\
(0.385)\end{array}$ & $\begin{array}{c}0.070 \\
(0.268)\end{array}$ & $\begin{array}{c}-0.348 \\
(0.248)\end{array}$ & $\begin{array}{c}-0.396 \\
(0.282)\end{array}$ & $\begin{array}{c}0.002 \\
(0.321)\end{array}$ & $\begin{array}{c}-0.225 \\
(0.390)\end{array}$ & $\begin{array}{c}-0.546 \\
(0.381)\end{array}$ \\
\hline flex & $\begin{array}{c}0.283 \\
(0.206)\end{array}$ & $\begin{array}{c}0.306 \\
(0.243)\end{array}$ & $\begin{array}{c}0.347 \\
(0.244)\end{array}$ & $\begin{array}{c}0.374 \\
(0.221)\end{array}$ & $\begin{array}{l}0.433^{*} \\
(0.228)\end{array}$ & $\begin{array}{c}0.394 \\
(0.244)\end{array}$ & $\begin{array}{c}0.372 \\
(0.257)\end{array}$ & $\begin{array}{c}0.436 \\
(0.280)\end{array}$ & $\begin{array}{c}0.410 \\
(0.308)\end{array}$ & $\begin{array}{c}0.318 \\
(0.313)\end{array}$ & $\begin{array}{c}0.291 \\
(0.321)\end{array}$ & $\begin{array}{c}0.384 \\
(0.310)\end{array}$ \\
\hline anchor & $\begin{array}{c}-0.891^{* *} \\
(0.380)\end{array}$ & $\begin{array}{c}-1.144^{* *} \\
(0.521)\end{array}$ & $\begin{array}{c}-1.147^{* *} \\
(0.470)\end{array}$ & $\begin{array}{c}-0.980^{* * *} \\
(0.425)\end{array}$ & $\begin{array}{c}-0.857^{* *} \\
(0.405)\end{array}$ & $\begin{array}{l}-0.546 \\
(0.366)\end{array}$ & $\begin{array}{c}-0.474 \\
(0.364)\end{array}$ & $\begin{array}{c}-0.472 \\
(0.359)\end{array}$ & $\begin{array}{l}-0.435 \\
(0.360)\end{array}$ & $\begin{array}{l}-0.184 \\
(0.379)\end{array}$ & $\begin{array}{c}-0.080 \\
(0.427)\end{array}$ & $\begin{array}{l}-0.192 \\
(0.441)\end{array}$ \\
\hline anchor X flex & $\begin{array}{c}0.288 \\
(0.326)\end{array}$ & $\begin{array}{c}0.636 \\
(0.447)\end{array}$ & $\begin{array}{c}0.521 \\
(0.383)\end{array}$ & $\begin{array}{c}0.129 \\
(0.340)\end{array}$ & $\begin{array}{c}-0.080 \\
(0.339)\end{array}$ & $\begin{array}{l}-0.558 \\
(0.400)\end{array}$ & $\begin{array}{c}-0.722^{*} \\
(0.419)\end{array}$ & $\begin{array}{c}-0.887^{* *} \\
(0.417)\end{array}$ & $\begin{array}{c}-1.013^{* *} \\
(0.491)\end{array}$ & $\begin{array}{c}-1.209^{* *} \\
(0.528)\end{array}$ & $\begin{array}{c}-1.335^{* *} \\
(0.634)\end{array}$ & $\begin{array}{c}-1.153^{*} \\
(0.604)\end{array}$ \\
\hline$\Delta$ ctot $\mathrm{X}$ anchor & $\begin{array}{c}0.848^{* *} \\
(0.369)\end{array}$ & $\begin{array}{c}0.170 \\
(0.312)\end{array}$ & $\begin{array}{c}-0.259 \\
(0.413)\end{array}$ & $\begin{array}{c}-0.570^{* *} \\
(0.234)\end{array}$ & $\begin{array}{l}-0.166 \\
(0.428)\end{array}$ & $\begin{array}{c}0.202 \\
(0.556)\end{array}$ & $\begin{array}{c}0.331 \\
(0.530)\end{array}$ & $\begin{array}{c}0.025 \\
(0.450)\end{array}$ & $\begin{array}{l}0.422^{*} \\
(0.247)\end{array}$ & $\begin{array}{l}1.488^{* *} \\
(0.568)\end{array}$ & $\begin{array}{c}0.594 \\
(0.621)\end{array}$ & $\begin{array}{c}0.218 \\
(0.432)\end{array}$ \\
\hline$\Delta$ ctot $\mathrm{X}$ anchor $\mathrm{X}$ flex & $\begin{array}{c}-1.924^{* * *} \\
(0.587)\end{array}$ & $\begin{array}{c}-1.799^{* * *} \\
(0.503)\end{array}$ & $\begin{array}{c}-1.979^{* *} \\
(0.841)\end{array}$ & $\begin{array}{c}-1.001^{* *} \\
(0.463)\end{array}$ & $\begin{array}{l}-1.081 \\
(0.834)\end{array}$ & $\begin{array}{c}-1.941^{* *} \\
(0.722)\end{array}$ & $\begin{array}{c}-1.665^{* *} \\
(0.677)\end{array}$ & $\begin{array}{l}-0.803 \\
(0.758)\end{array}$ & $\begin{array}{c}-1.654^{* * *} \\
(0.561)\end{array}$ & $\begin{array}{c}-2.771^{* * *} \\
(0.796)\end{array}$ & $\begin{array}{c}-1.803^{* *} \\
(0.823)\end{array}$ & $\begin{array}{c}-1.232^{* *} \\
(0.516)\end{array}$ \\
\hline Observations & 6,214 & 6,214 & 6,214 & 6,214 & 6,214 & 6,214 & 6,214 & 6,214 & 6,214 & 6,214 & 6,214 & 6,214 \\
\hline R-squared & 0.569 & 0.547 & 0.536 & 0.521 & 0.513 & 0.487 & 0.480 & 0.474 & 0.472 & 0.473 & 0.478 & 0.477 \\
\hline
\end{tabular}

Source: Authors' calculations.

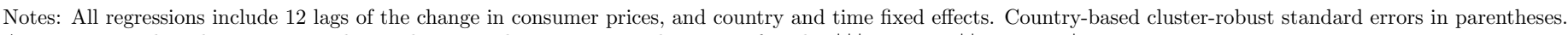

$\Delta$ ctot is reversed so that a positive change denotes a deterioration in the terms of trade. ${ }^{* * *} p<0.01, * * p<0.05, * p<0.1$. 